\title{
Kip/Cip and Ink4 Cdk inhibitors cooperate to induce cell cycle arrest in response to TGF- $\beta$
}

\author{
Inga Reynisdóttir, ${ }^{1}$ Kornelia Polyak, ${ }^{1,2}$ Antonio Iavarone, ${ }^{1}$ and Joan Massagué \\ Cell Biology and Genetics Program and Howard Hughes Medical Institute, Memorial Sloan-Kettering Cancer Center, New \\ York, New York 10021 USA
}

\begin{abstract}
$\mathbf{G}_{1}$ progression in mammalian cells requires the activity of the cyclin D-dependent kinases Cdk4 and/or Cdk6 and the cyclin E-dependent kinase Cdk2. Proliferating Mv1Lu mink lung epithelial cells and human keratinocytes contain high levels of the universal Cdk inhibitor $\mathbf{p 2} 7^{\text {Kip1 }}$ distributed in complexes with Cdk2, Cdk4, and Cdk6. Addition of the antimitogenic cytokine transforming growth factor- $\beta$ (TGF- $\beta$ ) elevates expression of the Cdk4/6-specific inhibitor $\mathrm{p}^{15^{\text {Ink4B }}}$ and induces the release of $\mathrm{p} 27$ from Cdk4 and Cdk6. In Mv1Lu cells, this release of p27 coincides with increased binding of p27 to Cdk2. Recombinant p15 inhibits p27 binding to Cdk4 in vitro, and p15 overexpression induces the transfer of p27 from Cdk4 to Cdk2 in vivo, suggesting that the release of Cdk4-bound p27 in TGF- $\beta$-treated cells is caused by the surge in p15 levels. In keratinocytes, TGF- $\beta$ increases not only p15 but also p21 ${ }^{\text {Cip1 }}$, which binds to Cdk2. These events correlate with Cdk2 inhibition and cell cycle arrest and occur without a loss of $G_{1}$ Cdk components. The results suggest that TGF- $\beta$ induces $G_{1}$ arrest in these two epithelial cell types by inhibiting various cyclin-Cdk kinases through the cooperative action of an Ink4 Cdk inhibitor and a Cip/Kip Cdk inhibitor. Subsequent to cell cycle arrest, Cdk2 and Cdk4 levels decline as part of a second set of events that may represent a program of cell adaptation to the quiescent state.
\end{abstract}

[Key Words: Cdk inhibitors; $\mathrm{p}^{7^{\text {Kip } 1}}$; $\mathrm{p} 15^{\text {Ink } 4 B} ; \mathrm{p} 21^{\text {Cip1 }}$; TGF- $\beta$; cell cycle arrest]

Received May 22, 1995; revised version accepted June 23, 1995.

Antimitogenic signals are essential for the maintenance of balanced tissue growth. These signals often act by inhibiting cyclin-dependent kinases (Cdks) involved in cell progression through $\mathrm{G}_{1}$ phase. In mammalian cells, $\mathrm{G}_{1}$ kinases include the cyclin E-Cdk2 complex and cyclin D complexes with Cdk4 and Cdk6 (Hunter and Pines 1994; Sherr 1994). $G_{1}$ kinases can be regulated by changes in cyclin or Cdk levels and by the activating kinase Cak (for review, see Sherr 1994). Additionally, $G_{1}$ kinases can be regulated by a set of proteins that inhibit Cdk activity through stoichiometric mechanisms /for review, see Peter and Herskowitz 1994b; Sherr and Roberts 1995). With their recent discovery in mammals and yeast, these Cdk inhibitors have attracted attention as possible mediators of antimitogenic signals. However, their role in these processes remains largely undefined.

Two families of mammalian $\mathrm{Cdk}$ inhibitors have been identified. One includes $\mathrm{p} 21^{\text {Cip } 1}$ (also known as WAF1, SDIl, or CAP20) (El-Deiry et al. 1993; Gu et al. 1993; Harper et al. 1993; Noda et al. 1994; Xiong et al. 1993), p2 $7^{\text {Kip1 }}$ (Polyak et al. 1994b; Toyoshima and Hunter

\footnotetext{
${ }^{1}$ The first three authors contributed equally to this study. ${ }^{2}$ Present address: The Johns Hopkins Oncology Center, Baltimore, Maryland 21231 USA
}

1994), and p57 ${ }^{\text {Kip2 }}$ (Lee et al. 1995; Matsuoka et al. 1995). In vitro, p21, p27, and p57 inhibit the activity of cyclin D-Cdk4, cyclin D-Cdk6, cyclin E-Cdk2 as well as cyclin A-Cdk2, a complex active during $\mathrm{S}$ phase (Gu et al. 1993; Harper et al. 1993; Xiong et al. 1993; Polyak et al. 1994b; Toyoshima and Hunter 1994; Lee et al. 1995; Matsuoka et al. 1995). These inhibitors can also prevent Cdk activation by Cak (Polyak et al. 1994b), however, they do not inhibit Cak directly (Kato et al. 1994b; Nourse et al. 1994). Cip/Kip inhibitors cause $G_{1}$ arrest when overexpressed in transfected cells, suggesting that despite some ability to inhibit the mitotic cyclin $\mathrm{B}-\mathrm{Cdc} 2$ complex in vitro, they do not act on mitotic Cdks in vivo (El-Deiry et al. 1993; Harper et al. 1993; Polyak et al. 1994b; Toyoshima and Hunter 1994). Overexpression of the conserved Cdk-binding/inhibitory domain from these inhibitors is sufficient to cause cell cycle arrest (Chen et al. 1995; Luo et al. 1995; Nakanishi et al. 1995). p21, but not $\mathrm{p} 27$ or $\mathrm{p} 57$, can additionally bind to proliferating cell nuclear antigen (PCNA), a polymerase $\delta$ accessory factor, and inhibit processive DNA replication (Flores-Rozas et al. 1994; Waga et al. 1994). This activity maps to the carboxy-terminal region of p21 (Chen et al. 1995; Luo et al. 1995; Warbrick et al. 1995) and can inhibit cell proliferation on its own (Luo et al. 1995). p57 
has a strongly acidic domain of unknown activity in its carboxy-terminal region (Lee et al. 1995; Matsuoka et al. 1995|, further suggesting that each of these inhibitors has a specialized function in the cell.

The second family of mammalian Cdk inhibitors includes p16 ${ }^{\text {Ink4 }}$ (Serrano et al. 1993), p15 ${ }^{\text {Ink4B }}$ (Hannon and Beach 1994), p18 $8^{\text {Ink4C }}$ (Guan et al. 1994; Hirai et al. 1995), and p19 ${ }^{\text {Ink4D }}$ (Chan et al. 1995; Hirai et al. 1995), all containing a fourfold repeated ankyrin-like sequence and showing no structural similarity to the Cip/Kip family. Ink4 inhibitors are specific for Cdk4 and Cdk6 and interfere with cyclin $\mathrm{D}$ binding to these kinases in vivo (Serrano et al. 1993; Guan et al. 1994; Chan et al. 1995; Hirai et al. 1995). As with the Cip/Kip inhibitors, overexpression of Ink4 inhibitors blocks cell proliferation (Guan et al. 1994; Hirai et al. 1995). The p15 and p16 genes reside contiguously on human chromosome $9 \mathrm{p} 21$ near a familial melanoma redisposition locus (Kamb et al. 1994; Nobori 1994). p16 is deleted or mutated at high rates in certain malignancies (Caldas et al. 1994; Mori et al. 1994), supporting the idea that Cdk inhibitors can act as tumor suppressor genes.

Evidence that Cdk inhibitors are involved in mediating negative regulation of cell proliferation has begun to accumulate. In response to radiation-induced DNA damage, the tumor suppressor p53 induces $G_{1}$ arrest by elevating p21 expression (El-Deiry et al. 1993, 1994). p21 expression is also elevated through p53-independent mechanisms that contribute to cell cycle exit during myoblast differentiation (Havely et al. 1995; Parker et al. 1995). The expression of p27 is high in cells inhibited by cell contact, by the cytokine transforming growth factor- $\beta$ (TGF- $\beta$ ), or by serum deprivation (Polyak et al. 1994a), and declines upon mitogenic stimulation of resting cells (Kato et al. 1994a; Nourse et al. 1994). Antiproliferative agents including cAMP in macrophages (Kato et al. 1994a) and rapamycin in T-lymphocytes (Nourse et al. 1994) prevent mitogen-induced p27 down-regulation. In the Ink 4 family, p15 expression is elevated by TGF- $\beta$ in human $\mathrm{HaCaT}$ keratinocytes (Hannon and Beach 1994). And in yeast, the Cdk inhibitor Farl mediates cell cycle arrest in response to mating factor (Peter and Herskowitz 1994a).

A general understanding of how cell proliferation is regulated by extracellular signals requires the identification of mechanisms that induce cell cycle arrest after a proliferative phase and mechanisms that maintain the quiescent state. The nature of such mechanisms can be explored through studies on the antimitogenic cytokine TGF- $\beta$ (for review, see Massagué 1990; Moses et al. 1990 ). Mechanisms offered previously to explain inhibition of cell proliferation by TGF- $\beta$ include suppression of Cdk4 synthesis (Ewen et al. 1993), down-regulation of cyclin and Cdk expression (Geng and Weinberg 1993; Satterwhite et al. 1994; Slingerland et al. 1994|, inhibition of Cdk2 and Cdk 4 complexes by p $27^{\text {Kip } 1}$ (Polyak et al. 1994a; Slingerland et al. 1994|, and inhibition of Cdk4 and Cdk6 kinases by p15 $5^{\text {Ink4B }}$ (Hannon and Beach 1994). This diversity defies the idea that TGF- $\beta$ could act through a single general mechanism to impart antimito- genic signals. In the present studies, however, a comprehensive analysis of TGF- $\beta$ effects on $G_{1}$ Cdks and Cdk inhibitors in two different epithelial cell types provides evidence reconciling previous findings. The present evidence indicates that TGF- $\beta$ induces cell cycle arrest through the cooperative action of $\mathrm{p} 15^{\text {Ink } 4 B}$ and $\mathrm{p} 27^{\text {Kip } 1}$, or $\mathrm{p} 21^{\mathrm{Cip} 1}$. TGF- $\beta$-induced cell cycle arrest is followed by a decline in Cdk levels as cells become quiescent.

\section{Results}

p27 ${ }^{\mathrm{Kip} 1}$ levels and phosphorylation state during cell exit from quiescence

The antimitogenic effects of TGF- $\beta$ have typically been studied by addition of this factor to cultured cells as they are relieved from contact inhibition. MvlLu mink lung epithelial cells released from contact inhibition reach $S$ phase within $\sim 15 \mathrm{hr}$, and this transition is prevented by addition of TGF- $\beta$ before mid- $G_{1}$ phase (Laiho et al. 1990). Upon release from contact inhibition, Cdk2 and Cdk4 levels increase and Cdk2 accumulates as a fastmigrating form that corresponds to its Cak-phosphorylated, active state (Ewen et al. 1993; Koff et al. 1993). TGF- $\beta$ addition causes extensive loss of Cdk 4 (Ewen et al. 1993) and prevents the accumulation of activated Cdk2 (Koff et al. 1993). These observations are recapitulated in Figure $1(\mathrm{~A}, \mathrm{~B})$.

Previous work indicated that $\mathrm{p} 27^{\mathrm{Kip} 1}$ is present in excess over endogenous cyclin-Cdk complexes in contactinhibited and TGF- $\beta$-inhibited MvlLu cells, and is present but bound to heat-labile components in proliferating cells (Polyak et al. 1994a). To study the levels and regulation of $\mathrm{p} 27$ and associated proteins, polyclonal antibodies were raised that recognize $\mathrm{p} 27$ but not $\mathrm{p} 21^{\mathrm{Cip} 1}$ or $\mathrm{p} 57^{\text {Kip } 2}$. Precipitation of contact-inhibited Mv1Lu cell lysates with these antibodies yielded a specific $27-\mathrm{kD}$ product (Fig. 1F) confirmed to be $\mathrm{p} 27$ by Western immunoblotting (data not shown). Specific coprecipitating products in the 32 - to $34-\mathrm{kD}$ range (Fig. 1F, bracket) included Cdk2 and Cdk4 as determined by anti-Cdk immunoblotting of anti-p27 precipitates (data not shown) or anti-p27 immunoblotting of anti-Cdk precipitates (Fig. 1D,E, first lanes).

Upon cell release from contact inhibition, total p27 levels were decreased by only one-half (Fig. 1C) or less, depending on the experiment. Simultaneously, the levels of $\mathrm{p} 27$ bound to $\mathrm{Cdk} 2$ and $\mathrm{Cdk} 4$ were slightly increased correlating with the increased levels of these Cdks in the cell (Fig. 1D,E). The pattern of metabolically labeled coprecipitating proteins confirmed that p27 binds to Cdks after cells enter the cell cycle (Fig. 1G). Furthermore, this pattern provided no evidence for $\mathrm{p} 27$ sequestration by a newly induced protein as cells enter the cell cycle.

Cells released from contact inhibition in the presence of TGF- $\beta$ contained no Cdk4-bound p27 (Fig. 1E) and yielded a lower level of associated Cdks upon coprecipitation with p27 (Fig. 1G). Both these phenomena were consistent with the observed loss of Cdk4 under these conditions. However, the partial loss of $\mathrm{Cdk} 2$ induced by 

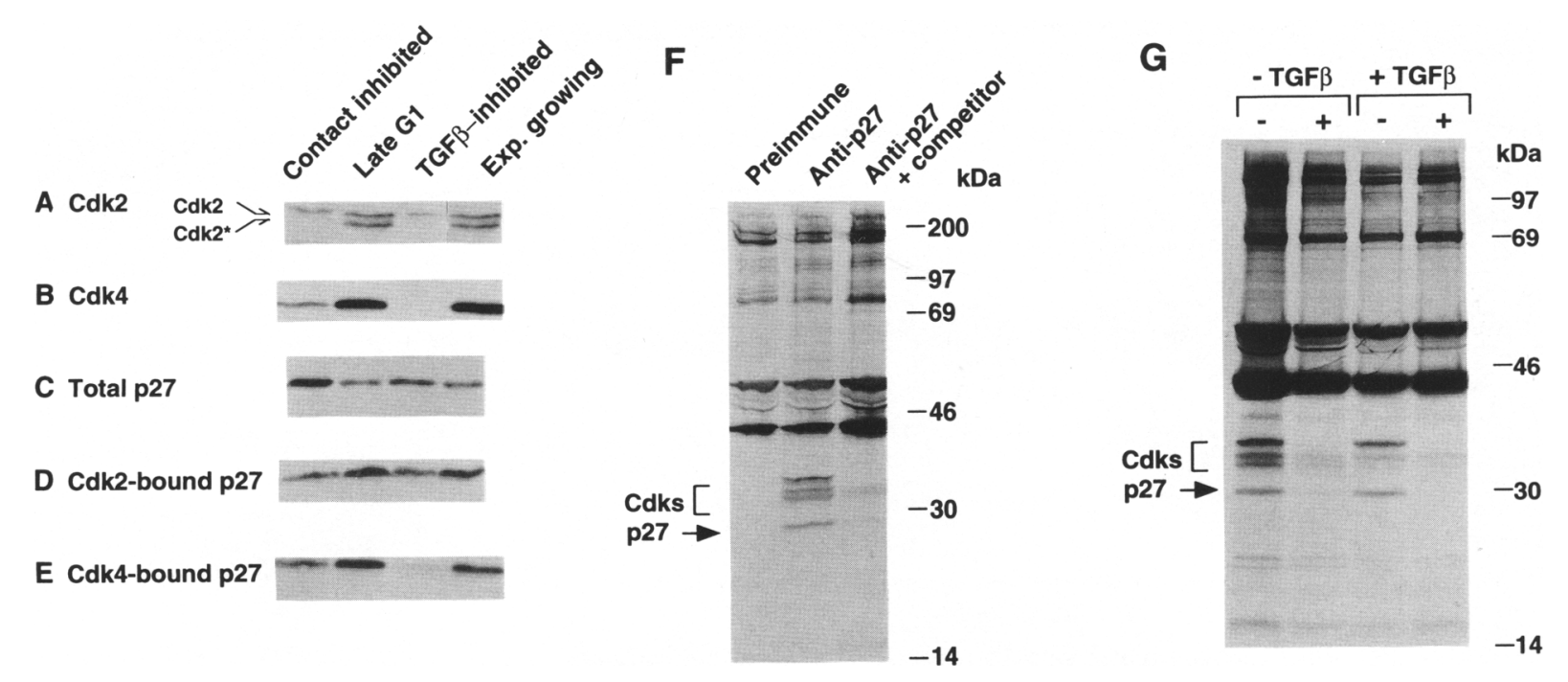

Figure 1. Cdk and p27 levels, and association during cell release from contact inhibition. The levels of Cdk2, Cdk4, total p27, Cdk2-bound p27 and Cdk4-bound p27, were analyzed in Mv1Lu cells that were contact inhibited, released from contact inhibition by being seeded sparsely for $15 \mathrm{hr}$ in growth medium alone (late $G_{1}$ ) or in the presence of $100 \mathrm{pM}$ TGF- $\beta$ (TGF- $\beta$-inhibited). Samples from exponentially proliferating cultures were run in parallel. Cell extracts $(2 \mathrm{mg}$ of protein) from these various conditions were immunoprecipitated with anti-Cdk2 antibody $(A, D)$ or anti-Cdk4 antibody $(B, E)$, resolved by SDS-PAGE, and the proteins were visualized with Cdk2 antibody $(A), \mathrm{Cdk} 4$ antibody $(B)$, or p27 antiserum $(D, E)$. Smaller aliquots $(0.2 \mathrm{mg}$ of protein) of extract were directly subjected to SDS-PAGE and probed with $\mathrm{p} 27$ antiserum $(C)$. Cdk2 ${ }^{\star}$ denotes the active phosphorylated form of Cdk2. In $F$, lysates from contact inhibited ${ }^{35}$ S $]$ methionine-labeled $\mathrm{MvlLu}$ cells were immunoprecipitated with preimmune serum, p27 antiserum, or p27 antiserum that was preblocked by incubation with an excess of recombinant mouse $\mathrm{p} 27$. In $G, \mathrm{Mv} 1 \mathrm{Lu}$ cells were released from contact inihibition in the absence or presence of 100 pM TGF- $\beta$, metabolically labeled with $\left[{ }^{35}\right.$ S $]$ methionine, and precipitated with p27 antiserum that had been preblocked with excess recombinant $\mathrm{p} 27$, as competitor, where indicated. $(+)$ The proteins were analyzed on SDS-PAGE and fluorography. The arrow points to $\mathrm{p} 27$, and the bracket indicates the bound Cdks.

TGF- $\beta$ was not accompanied by a loss in Cdk2-bound p27 (compare Fig. 1A,D), suggesting a higher saturation of the remaining Cdk2 with p27. The loss of Cdk4 in cells that received TGF- $\beta$ at the time of release from contact inhibition might favor $\mathrm{p} 27$ binding to $\mathrm{Cdk} 2$, thus helping prevent cell exit from quiescence.

Cell cycle regulatory proteins are often regulated by phosphorylation. p27 immunoprecipitation from ${ }^{32} \mathrm{P}-1 \mathrm{a}-$ beled cells yielded a pattern of labeled products similar to that obtained from $\left[{ }^{35} \mathrm{~S}\right]$ methionine labeled cells, suggesting that p27 is a phosphoprotein. However, the p27 phosphorylation level was similar in contact-inhibited cells and in cells released from inhibition with serum alone or serum plus TGF- $\beta$ and was not changed by a short $(10 \mathrm{~min})$ incubation of exponentially growing cells with TGF- $\beta$ (data not shown). p27 isolated from these various conditions yielded the same proteolytic phosphopeptide pattern and in all cases contained phosphoserine and phosphothreonine at a 10:1 ratio and no phosphotyrosine (data not shown). Because the phosphorylation state of p27 was not changed under these conditions, further studies were focused on the interaction of p27 with its target Cdks.

\section{Cdk2 response to TGF- $\beta$ in proliferating cells}

The preceding results suggested that TGF- $\beta$ can abort cell exit from quiescence. However, as a physiological regulator of epithelial tissue homeostasis, TGF- $\beta$ is likely to act by arresting actively proliferating cells and not just by preventing entry of quiescent cells into the cell cycle. Therefore, we investigated the events that lead to cell cycle arrest when TGF- $\beta$ is added to proliferating MvlLu lung epithelial cells and human keratinocytes. Cycling time during exponential growth was 19 $\mathrm{hr}$ in MvlLu cells, $21 \mathrm{hr}$ in $\mathrm{HaCaT}$ human keratinocytes and $40 \mathrm{hr}$ in human primary keratinocytes, with a higher proportion of cells in $G_{1}$ phase in MvlLu cells than in keratinocytes (Fig. 2A). Addition of TGF- $\beta$ to exponentially growing cultures inhibited DNA synthesis and induced arrest with a $G_{1}$ DNA content (Fig. 2A,B). Inhibition of DNA synthesis occurred earlier in MvlLu cells $\left(t_{1 / 2}=8 \mathrm{hr}\right)$ than in keratinocytes $\left(t_{1 / 2}=\sim 12 \mathrm{hr}\right)$ (Fig. $\left.2 \mathrm{~B}\right)$.

Cell cycle components of interest were assayed in cell extracts at various times after TGF- $\beta$ addition. Cdk2associated kinase activity, which is rate-limiting for progression into S phase (Sherr 1993), was used as a general indicator of inhibitory events. TGF- $\beta$ caused an essentially complete loss of Cdk2 kinase activity in all three cell types (Fig. 2C). The decrease in Cdk2 kinase activity was detectable within $4 \mathrm{hr}$ of TGF- $\beta$ addition in MvlLu cells and within $12 \mathrm{hr}$ in keratinocytes. Notably, loss of Cdk2 kinase activity was not due to a decrease in Cdk2 protein levels, as determined by anti-Cdk2 immunoblotting (Fig. 2D). A loss of the fast-migrating, activated form of $\mathrm{Cdk} 2$ was observed in response to TGF- $\beta$, but it lagged 


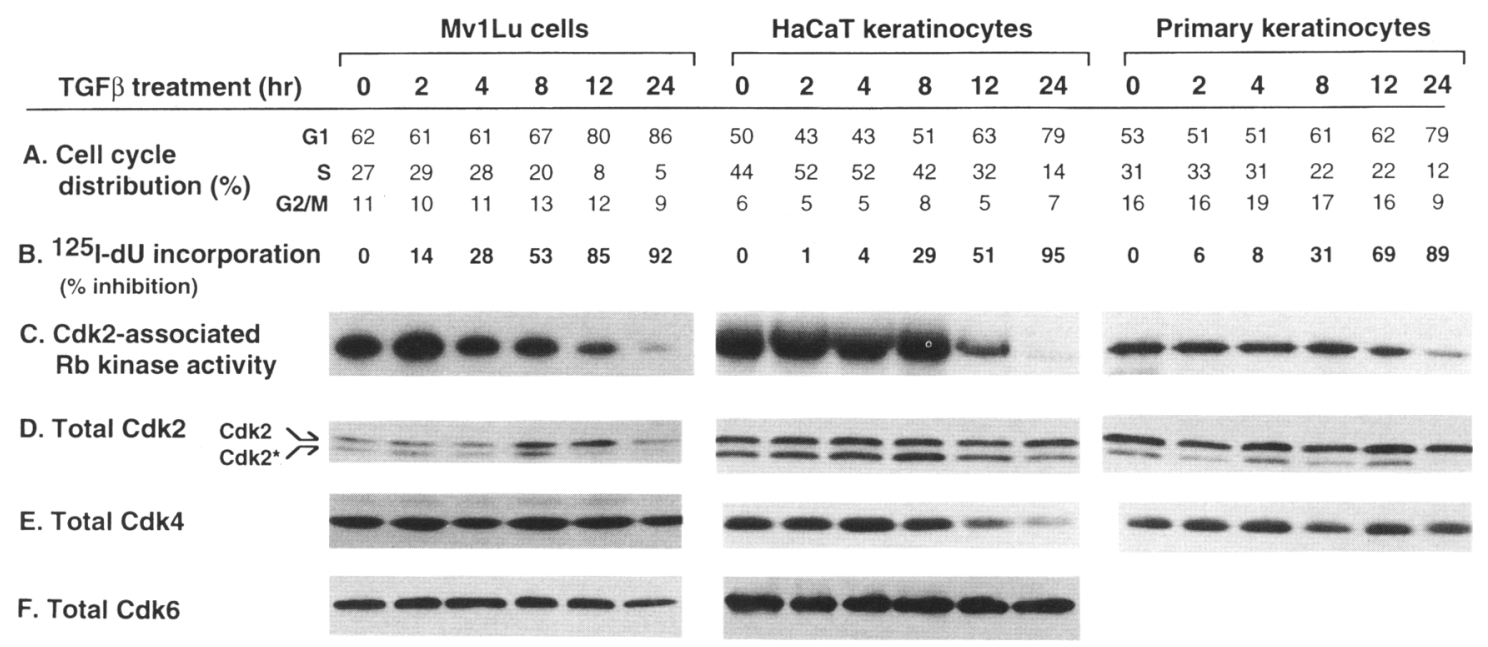

Figure 2. TGF- $\beta$ effects on exponentially proliferating MvlLu cells, HaCaT keratinocytes, and human primary keratinocytes. Exponentially growing MvlLu cells and keratinocytes were treated with TGF- $\beta$ for the indicated times. Cell cycle distribution was determined by flow cytometry $(A)$. DNA synthesis was determined by $\left[{ }^{125} \mathrm{I}\right]$ deoxyuridine $(\mathrm{dU})$ incorporation, assayed in triplicate and expressed as percent inhibition relative to untreated controls $(B)$. Cdk2-associated kinase activity was examined in Cdk2 immunoprecipitates with a GST-Rb fusion protein as a substrate $(C)$. Levels of Cdk2 $(D)$, Cdk4 $(E)$ and Cdk6 $(F)$ were analyzed by immunoprecipitation and immunoblotting with the respective antibodies.

several hours behind the loss of Cdk2 kinase activity (Fig. 2D).

The levels of cyclin A in MvlLu cells were decreased after a long exposure to TGF- $\beta$ (between 12 and $24 \mathrm{hr}$, data not shown). Even though the decline in cyclin A levels may contribute to the complete loss of Cdk2 kinase activity after long treatments with TGF- $\beta$, this effect probably reflects $a G_{1}$ block before the onset of cyclin A expression at the $G_{1} / S$ boundary is reached (Sherr 1994). As determined by Western immunoblotting, the levels of cyclins $E$ and D1 remained unchanged over the period of TGF- $\beta$ treatment (data not shown). Taken together, these results suggested that the early decline in Cdk2-associated kinase activity was not due to a loss of Cdk2 components but to an inhibitory action on Cdk2 complexes. Therefore, we investigated the possible role of Cdk inhibitors in this response.

\section{Down-regulation of $C d k 4$ and $C d k 6$ are late TGF- $\beta$ effects}

As in MvlLu cells released from contact inhibition, a possible source of Cdk2 inhibitory activity in exponentially proliferating cells treated with TGF- $\beta$ could be p 27 mobilized from lost Cdk4. However, TGF- $\beta$ addition to proliferating MvlLu cells for up to $24 \mathrm{hr}$ had essentially no effect on Cdk4 levels (Fig. 2E) nor did it affect the level of Cdk6 (Fig. 2F), a Cdk functionally related to Cdk4 (Meyerson and Harlow 1994). TGF- $\beta$ did decrease Cdk4 levels in proliferating $\mathrm{HaCaT}$ cells, but only after $12 \mathrm{hr}$ of treatment (Fig. 2E). Unfortunately, the in vivo kinase activity of Cdk4 could not be measured because the available Cdk4 antibodies did not immunoprecipitate Cdk4 with detectable kinase activity. Similar diffi- culties have also been encountered by others (Hannon and Beach 1994).

$\mathrm{HaCaT}$ cells were originated by spontaneous immortalization of human keratinocytes in culture (Boukamp et al. 1988) and contain inactivating mutations in p53 (Lehman et al. 1993). Because p53 appears to be involved in Cdk4 down-regulation by TGF- $\beta$ (Ewen et al. 1995), the presence of mutant $\mathrm{p} 53$ in $\mathrm{HaCaT}$ cells might have compromised their ability to down-regulate $\mathrm{Cdk} 4$ in response to TGF- $\beta$. To address this concern we used primary human keratinocytes, which are assumed to be p53 positive. However, TGF- $\beta$ addition for up to $24 \mathrm{hr}$ was also ineffective at decreasing Cdk4 levels in primary keratinocytes (Fig. 2E), even though the cells were already growth arrested at that point.

To reconcile the lack of a rapid TGF- $\beta$ effect on Cdk4 levels in proliferating cells with the observation that TGF- $\beta$ inhibits Cdk4 accumulation in MvlLu cells (Ewen et al. 1993), we determined the rate of Cdk4 synthesis in MvlLu cells and $\mathrm{HaCaT}$ cells at various times after TGF- $\beta$ addition. Metabolic labeling with $\left[{ }^{35} \mathrm{~S}\right] \mathrm{me}$ thionine for $1 \mathrm{hr}$, and Cdk4 immunoprecipitation showed that TGF- $\beta$ addition did decrease Cdk 4 synthesis but only after $12 \mathrm{hr}$ in MvlLu cells and $8 \mathrm{hr}$ in HaCaT cells (Fig. 3A). The half-life of Cdk4 was $6 \mathrm{hr}$ in both cell types (data not shown), which is consistent with the lack of an early effect of TGF- $\beta$ on Cdk 4 levels. The Cdk6 synthesis rate was decreased only slightly by TGF- $\beta$ in MvlLu cells (Fig. 3B) and in HaCaT cells (data not shown). These results argued that $\mathrm{Cdk} 4$ down-regulation by TGF- $\beta$ is too late a response to be a primary cause of cell cycle arrest in Mv1Lu cells or primary keratinocytes, although it could be a contributing factor in $\mathrm{HaCaT}$ cells. 


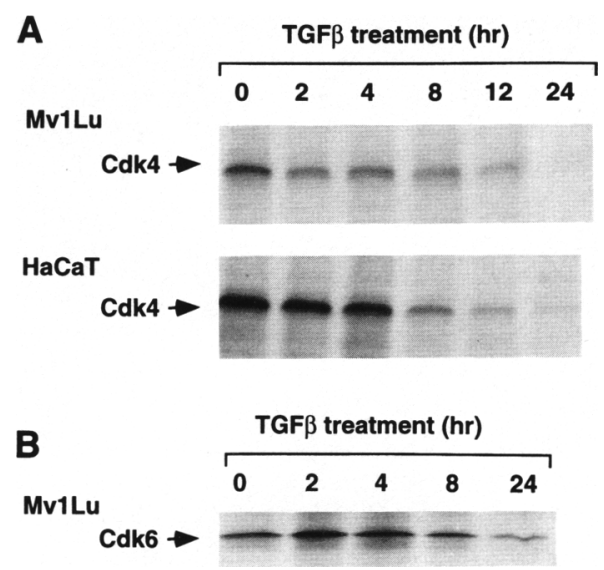

Figure 3. Cdk4 down-regulation is a late TGF- $\beta$ effect in MvlLu and HaCaT cells. Exponentially growing MvlLu and $\mathrm{HaCaT}$ cells were treated with 100 pM TGF- $\beta$ for the indicated times. $\left[{ }^{35} \mathrm{~S}\right]$ Methionine was included in the last hour of incubation with TGF- $\beta$. Cell extracts were precipitated with either Cdk4 antibody $(A)$ or Cdk6 antibody $(B)$ and subjected to SDSPAGE and fluorography.

In contrast to proliferating Mvl Lu cells, TGF- $\beta$ is able to maintain low levels of Cdk4 in MvlLu cells emerging from contact inhibition (Fig. 1B; Ewen et al. 1993). It is possible that TGF- $\beta$ could be perpetuating the contact inhibited state that already has low levels of Cdk4.

\section{p27 transfer from Cdk4 and Cdk6 to Cdk2}

To determine whether p27 was involved in Cdk2 inhibition by TGF- $\beta$ in exponentially growing cells, total cell extracts as well as Cdk2, Cdk4, and Cdk6 immunoprecipitates were subjected to anti-p27 immunoblotting. In MvlLu cells, TGF- $\beta$ increased total p27 levels only marginally (Fig. 4A); however, it increased the level of Cdk2bound p27 four- to sixfold ( $n=3$ ) (Fig. 4B). This increase occurred 4-8 hr after TGF- $\beta$ addition and remained high for at least $24 \mathrm{hr}$. Remarkably, the gain in Cdk2-bound p27 correlated with a complete loss of Cdk4-bound and Cdk6-bound p27 (Fig. 4C,D). These results suggested that TGF- $\beta$ inhibited Cdk2 by mobilizing $\mathrm{p} 27$ from complexes with Cdk4 and Cdk6. A similar phenomenon was observed in $\mathrm{HaCaT}$ cells but with a significant difference that for purposes of clarity is described separately below.

\section{p15 $5^{\text {Ink4B }}$ response in Mv1Lu cells}

To determine the basis for the TGF- $\beta$-induced release of Cdk4-bound p27 in MvlLu cells, we turned our attention to $\mathrm{pl} 5^{\text {Ink }} 4$. . This protein binds to and inhibits Cdk4 and Cdk6 but not Cdk2, and its expression is strongly elevated by TGF- $\beta$ in HaCaT cells (Hannon and Beach 1994). p15 accumulating in response to TGF- $\beta$ might compete with p27 for binding to Cdk4 and Cdk6 without interfering with $\mathrm{p} 27$ binding to Cdk2, thus favoring $\mathrm{p} 27$ binding to Cdk2. We investigated this hypothesis by first determining whether the $\mathrm{p} 15$ response to TGF- $\beta$, previously described in $\mathrm{HaCaT}$ cells, occurred also in MvlLu cells.

pl $5^{\text {Ink4B }}$ mRNA levels in MvlLu cells were examined with a cDNA probe amplified from Mv1Lu mRNA with primers that flank nucleotides $24-115$ in the human $\mathrm{p} 15^{\text {Ink } 4 B}$ cDNA sequence, a region of maximal divergence between p15 and other known Ink4 family members (Serrano et al. 1993; Guan et al. 1994; Chan et al. 1995; Hirai et al. 1995). The amplified mink cDNA segment encoded an amino acid sequence $70 \%$ similar to the corresponding human p15 sequence and $35 \%$ similar to the other known Ink4 family members. In Northern blot assays, this probe hybridized to two mRNA species (2.2 and $3.5 \mathrm{~kb}$ ) from contact-inhibited MvlLu cells (Fig. $5 \mathrm{~A}$ |, a pattern similar to that observed in human $\mathrm{HaCaT}$ cells (Hannon and Beach 1994). Mv1Lu p15 mRNA levels decreased by approximately one-half upon cell release from contact inhibition and increased several-fold in cells released in the presence of TGF- $\beta$ (Fig. 5A). TGF- $\beta$ addition to exponentially growing MvlLu cells elevated p15 mRNA levels $\sim 15$-fold, this response being detectable at $2 \mathrm{hr}$, maximal at $4 \mathrm{hr}$ and sustained for at least 18 $\mathrm{hr}$ after TGF- $\beta$ addition (Fig. 5B). Available anti-human p15/p16 antibodies did not detect mink p15. However, Cdk6 immunoprecipitation from metabolically labeled $\mathrm{Mv} 1 \mathrm{Lu}$ cells revealed a specific coprecipitating protein of $15 \mathrm{kD}$ whose levels increased in response to TGF- $\beta$ in parallel with the increase in p1 $5^{\text {Ink } 4 B}$ mRNA levels (Fig. $5 \mathrm{C})$.

TGF- $\beta$ elevates $\mathrm{p} 21^{\text {Cip } 1}$ expression in ovarian carcinoma cell lines (Elbendary et al. 1994) and $\mathrm{HaCaT}$ cells (see below). However, p21 expression was low in contact-inhibited, TGF- $\beta$-inhibited or proliferating MvlLu cells. No $557^{\text {Kip } 2}$ mRNA was detected under any of these culture conditions (data not shown).

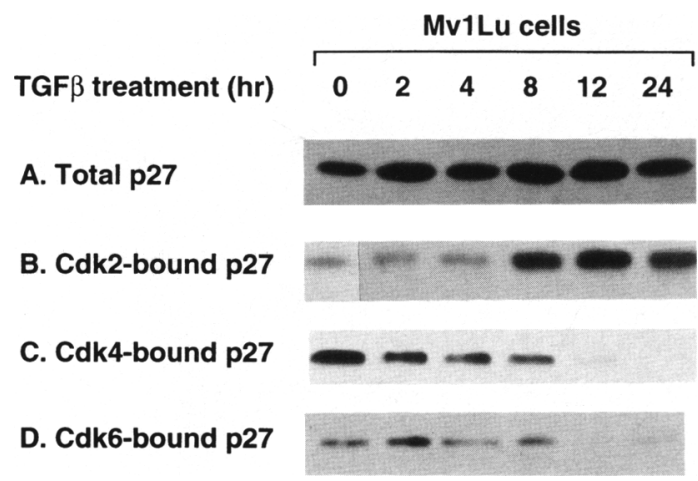

Figure 4. TGF- $\beta$ effects on p27 and Cdk-bound p27 in MvlLu cells. Exponentially growing Mv1Lu cells were treated with TGF- $\beta$ for the indicated time. $(A)$ p 27 was analyzed by direct immunoblotting of total cell extracts $(0.2 \mathrm{mg})$. The levels of Cdk2-associated p27 $(B)$, Cdk4-associated p27 $(C)$, and Cdk6associated p27 $(D)$ were examined by immunoprecipitation with the respective antibodies and subsequent immunoblotting with p27 antibody. The amounts of extracts used for the immunoprecipitations were $2 \mathrm{mg}(B), 5 \mathrm{mg}(C)$, and $4 \mathrm{mg}(D)$. 

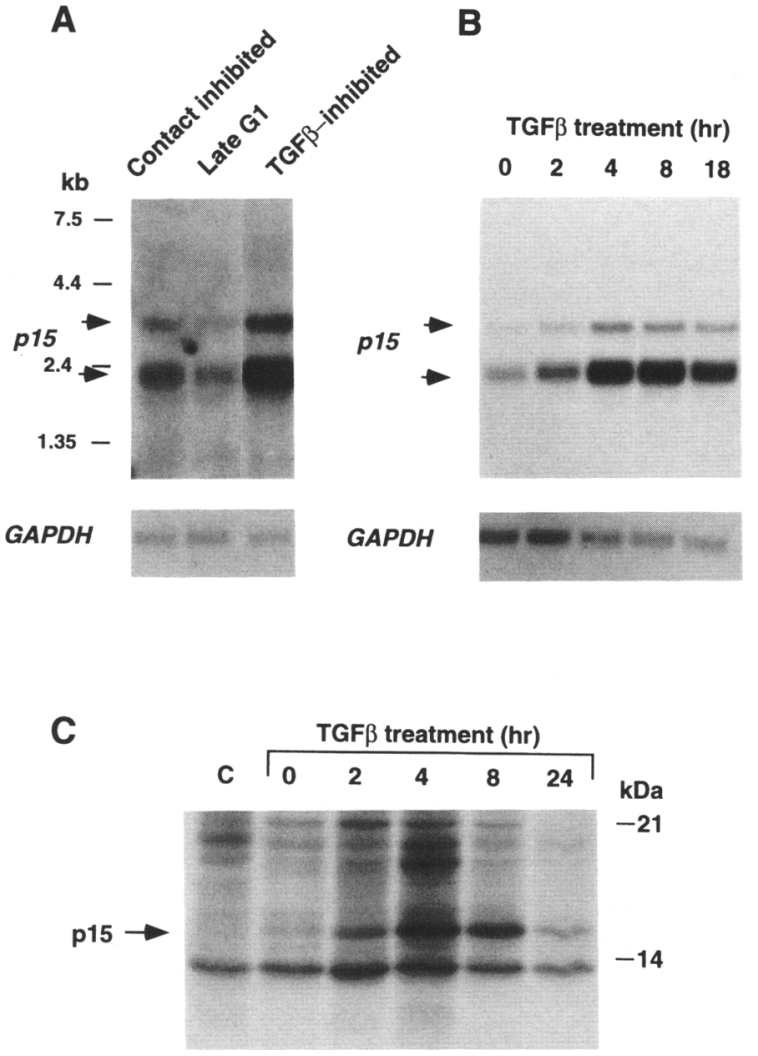

Figure 5. $\mathrm{p} 15^{\text {Ink4B }}$ mRNA and protein response to TGF- $\beta$ in MvlLu cells. $(A, B)$ Northern blot analysis of p1 $5^{\text {Ink4B }}$ mRNA levels with poly $(A)^{+}$RNA from MvlLu cells during the indicated proliferative states $(A)$ or after treatment of exponentially growing cells with 100 pM TGF- $\beta$ for the indicated times $(B)$. The blots were reprobed with a glyceraldehyde-3-phosphate dehydrogenase $(G A P D H)$ cDNA probe, a housekeeping gene, to control for RNA loading. (C) Analysis of Cdk6-associated p15 in MvlLu cells treated with TGF- $\beta$ for the indicated times. Cells were metabolically labeled with $\left[{ }^{35} \mathrm{~S}\right]$ methionine for the last 2 hr of incubation with TGF- $\beta$, precipitated with Cdk6 antibody, and subjected to SDS-PAGE and fluorography. An aliquot of the $8 \mathrm{hr}$ extract was immunoprecipitated with preimmune serum as control (lane C). The position of p15 (arrow) is indicated.

\section{p15 inhibition of p27 binding to Cdk4 in vivo and in vitro}

To determine whether an increase in $\mathrm{p} 15$ could decrease p27 binding to Cdk4 and concomitantly increase p27 binding to Cdk2 in vivo, we transfected a human p15 expression vector (pCMV5-p15) into a MvlLu subclone (R-1B/L17) under high efficiency conditions that allow $\sim 60 \%$ of the cells to take up exogenous DNA (Attisano et al. 1993). Under these conditions, p15 transfection caused a $60 \%$ decrease in [ $\left.{ }^{125} \mathrm{I}\right]$ deoxyuridine incorporation into DNA. Western immunoblot analysis of total cell lysates with anti-p27 and anti-p15 antibodies showed that p15 overexpression did not decrease the level of p27 in the cell (Fig. 6A). However, p15 overexpression decreased by one-half the level of Cdk4-bound p27 and concomitantly increased the level of Cdk2- bound p27 (Fig. 6B). Because these changes occurred under conditions in which only about half of the cells overexpressed p15, it is suggested that a quantitative loss of Cdk4-bound p27 occurred in the p15-overexpressing cells.

We confirmed the ability of p15 to decrease p27 binding to cyclin $\mathrm{D}-\mathrm{Cdk} 4$ complexes using recombinant proteins in vitro. Insect cell extracts containing recombinant cyclin D2 and Cdk4 were preincubated with varying amounts of purified recombinant p15 for $30 \mathrm{~min}$ and then incubated with in vitro-translated ${ }^{35} S$-labeled p27. After incubation, Cdk4-bound p27 was isolated by antiCdk4 immunoprecipitation, separated by SDS-PAGE and quantitated by fluorography. This experiment showed that addition of p15 reproducibly decreased $\mathrm{p} 27$ binding to Cdk4 (Fig. 7). p27 binds only to cyclin-Cdk complexes (Polyak et al. 1994b), whereas Ink4 Cdk inhibitors can also bind to free Cdk4 (Serrano et al. 1993; Guan et al. 1994; Hannon and Beach 1994). It is possible that under our experimental conditions the added p15 induced the dissociation of cyclin D-Cdk4 complexes as previously observed under some conditions (Guan et al. 1994) but not others (Hirai et al. 1995). It is also possible that some p15-bound Cdk4 complexes still retained bound $\mathrm{p} 27$. When added simultaneously with $\mathrm{p} 27, \mathrm{p} 15$ was much less effective at decreasing $\mathrm{p} 27$ binding to cyclin D-Cdk4 (data not shown), suggesting that prior occupancy and/or dissociation of the cyclin D-Cdk4 complex by p1 5 contributes to the inhibition of $\mathrm{p} 27$ binding in vitro.

\section{Minimal p27 levels required for Cdk2 inhibition and cell cycle arrest}

The preceding results suggested that $\mathrm{MvlLu}$ cells retain substantial levels of p27 after they enter the cell cycle, and these levels might be sufficiently high to inhibit Cdk2 when not spent in complexes with other Cdks. The levels of total p27 and Cdk2 in exponentially grow-

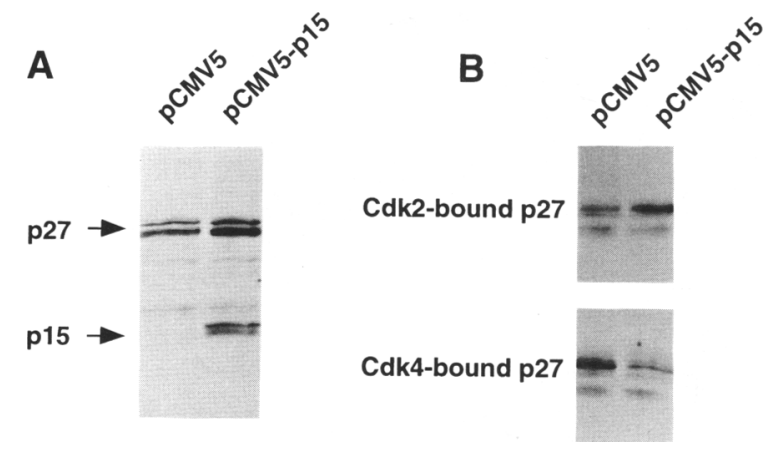

Figure 6. p15 overexpression induces a shift in p27 from Cdk4 to Cdk2. R1B/L17 cells were transiently transfected with pCMV5 or pCMV5-p15. The levels of p15 and p27 were examined by immunoblots on whole-cell extracts $(A)$. The amount of p27 associated with Cdk2 or Cdk4 was analyzed by anti-p27 immunoblotting of Cdk2 and Cdk4 immunoprecipitates $(B)$. 


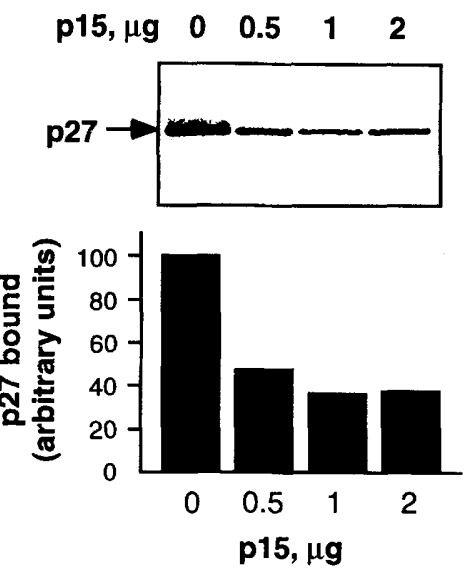

Figure 7. p15 inhibits p27 association with cyclin D-Cdk4. Insect cell lysates containing baculovirally expressed cyclin D2 and Cdk4 were preincubated with the indicated concentrations of recombinant p15 for $30 \mathrm{~min}$ and then received $30 \mathrm{ng}$ of ${ }^{35} \mathrm{~S}$ labeled p27 from an in vitro translation. The amount of p27 in the CDK complex was determined by precipitation with anti Cdk4 antibody, followed by SDS-PAGE and fluorography $(A)$, and the signal was quantitated on a PhosphorImager and plotted $(B)$. The position of $\mathrm{p} 27$ in the gels is indicated.

ing MvlLu cells were 0.39 pmole $/ 10^{6}$ cells and 0.49 pmole $/ 10^{6}$ cells, respectively, as quantitated by Western immunoblotting with known amounts of the recombinant proteins as standards. Only a portion of the total Cdk2 is in complex with cyclins in these cells (Koff et al. 1993). Therefore, MvlLu cells appear to contain closely matched levels of p27 and Cdk2.

If the levels of Cdks and p27 in the cell were as closely adjusted as suggested by these results, it should be possible to show that a small increase in available p27 could cause a strong inhibition of Cdk2 activity and lead to cell cycle arrest. To test this possibility, we generated MvlLu clones in which expression of a transfected p27 was tightly controlled by an inducible system that is based on the bacterial tetracycline resistance repressor (Gossen and Bujard 1992). MvlLu cells were transfected with a vector encoding the tetracycline repressor fused to the activating domain of the herpes simplex virus transcriptional activator VP16, and a second vector containing the mouse p27 cDNA under the control of the tetracycline operon regulatory elements. This system allows the expression of the desired protein, p27 in this case, in the absence of tetracycline but not in the presence of the drug.

Stable cell lines were generated with these two vectors, and two independent clones, 14.5 and 14.8, were analyzed in detail, giving the same results. In the presence of $2 \mu \mathrm{g} / \mathrm{ml}$ of tetracycline, the basal levels of p27 in exponentially growing cultures of these two cell lines were similar to the levels in a negative control (clone 14.1) not expressing exogenous p27 (Fig. 8A,B) or in parental Mv1Lu cells (data not shown). In tetracycline-free medium, p27 levels in clones 14.5 and 14.8 were 25 -fold over basal (Fig. 8A,B). This increase was near maximal 6 hr after tetracycline removal, and correlated with increases in the levels of Cdk2-bound p27 and Cdk4-bound p27 (Fig. 8A). DNA synthesis rates correlated with the levels of p27. At $2 \mu \mathrm{g} / \mathrm{ml}$ of tetracycline, when exogenous p27 was not expressed, clones 14.5 and 14.8 had DNA synthesis rates similar to those of clone 14.1 or parental MvlLu cells. In tetracycline-free medium, clones 14.5 and 14.8 were growth-arrested, whereas clone 14.1 synthesized DNA at the same rate as in tetracycline medium. Flow cytometry analyses confirmed that the arrest in p27-overexpressing cells was in $G_{1}$ (data not shown). Mouse p27 migrates slightly faster than mink p27 on SDS-PAGE gels, a property that helped establish that the p27 increase upon tetracycline removal was due to elevated expression of the exogenous mouse p27 (Fig. 8A,B).

Expression of exogenous $\mathrm{p} 27$ in clones 14.5 and 14.8 was induced at tetracycline concentrations of $13 \mathrm{ng} / \mathrm{ml}$ and lower. In cells incubated with $10 \mathrm{ng} / \mathrm{ml}$ of tetracycline for $18 \mathrm{hr}$, exogenous p27 reached a level equal to the level of endogenous p27, thereby doubling the basal level (Fig. 8B). The Cdk2-associated kinase activity in these cells was as high as in uninduced cells (Fig. 8B), and DNA synthesis rates measured at $18 \mathrm{hr}$ (Fig. $8 \mathrm{C}$ ) or $22 \mathrm{hr}$ showed only a small reduction compared to rates in uninduced cells. However, a threefold increase in total p27 levels obtained by incubation with $7.5 \mathrm{ng} / \mathrm{ml}$ of tetracycline correlated with a $50 \%$ inhibition of both Cdk2 kinase activity and DNA synthesis rate. A sevenfold increase in p27 levels obtained at $5 \mathrm{ng} / \mathrm{ml}$ of tetracycline inhibited Cdk2 kinase activity by $90 \%$ and DNA synthesis by $75 \%$ (Fig. $8 \mathrm{~B}, \mathrm{C}$ ).

These results indicated that the total Cdk pool in exponentially growing MvlLu cells could absorb a twofold increase in p27 levels without severely compromising cell cycle progression, whereas a further increase in p27 levels, however modest, had a profound inhibitory effect (Fig. 8D). Because an increase in p27 levels in this inducible system becomes absorbed by other Cdks besides Cdk2 (see Fig. 8A), an even smaller increase should inhibit Cdk2 when other Cdks, such as Cdk4 and Cdk6 in TGF- $\beta$-treated cells, do not participate in binding p27. The four- to sixfold increase in Cdk2-bound p27 observed in TGF- $\beta$-treated MvlLu cells should therefore suffice to inhibit all Cdk2 activity.

\section{Involvement of $p 21$ in the TGF- $\beta$ response in HaCaT cells}

As in MvlLu cells, the induction of cell cycle arrest by TGF- $\beta$ in $\mathrm{HaCaT}$ cells was initiated without a loss of Cdk2, Cdk4, or Cdk6 (see Fig. 2) and involved a rapid increase in p15 $5^{\text {Ink } 4 B}$ mRNA levels (Fig. 9A; Hannon and Beach 1994) and a concomitant loss of Cdk4-bound p27 and Cdk6-bound 27 (Fig. 10C,D). In contrast to MvlLu cells, however, $\mathrm{HaCaT}$ cells did not show a marked gain in Cdk2-associated p 27 until $24 \mathrm{hr}$ after TGF- $\beta$ addition (Fig. 10B), and this increase correlated with an increase in total p27 levels (Fig. 10A). Quantitative Western immunoblot assays showed that the levels of p27 and Cdk2 
A

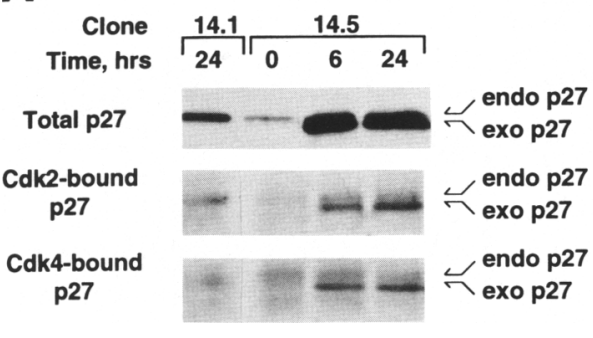

B

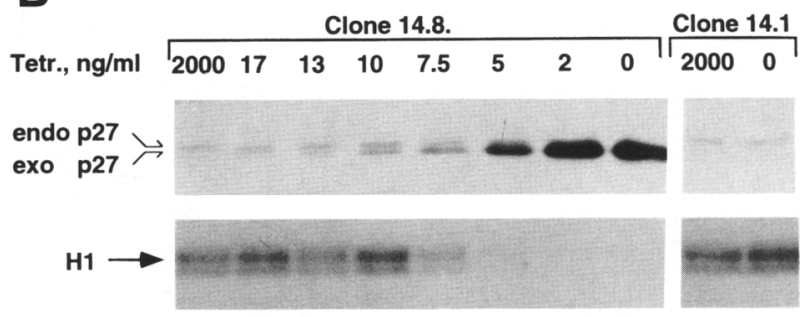

C
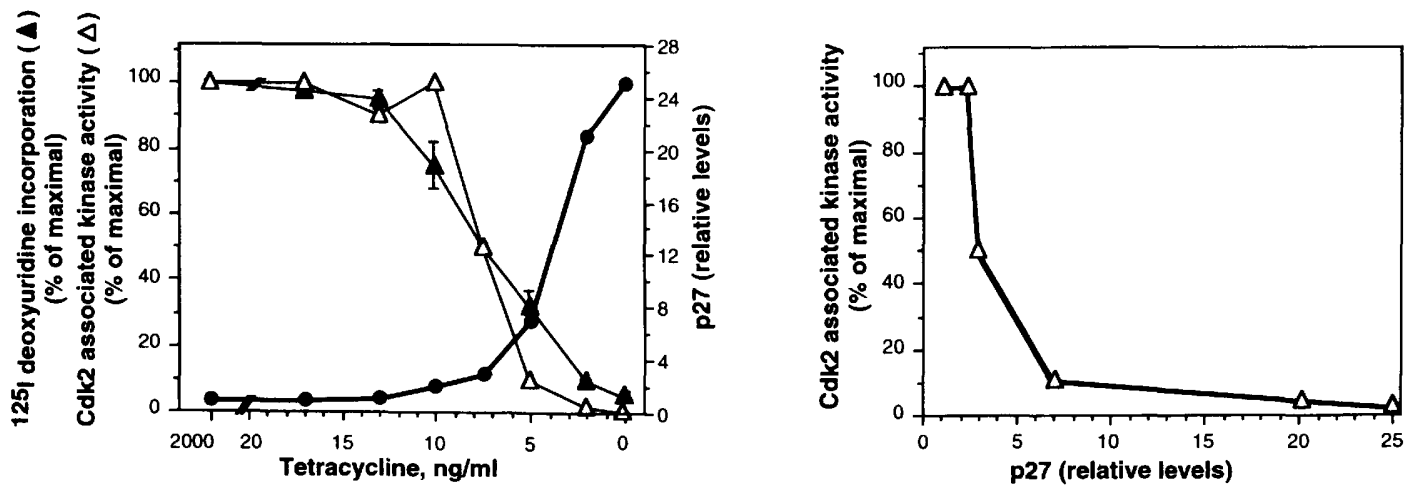

Figure 8. Cdk2 kinase inhibition and cell cycle arrest in a p27 inducible expression system. $(A)$ Clones 14.1 and 14.5 were grown in tetracycline-free medium for the indicated times. Total cell extracts ( $5 \mu \mathrm{g}$ of protein), or the anti-Cdk2 and anti-Cdk4 immunoprecipitates from these extracts ( 1 and $2 \mathrm{mg}$ of protein, respectively) were subjected to SDS-PAGE and immunoblotting with p27 antiserum. The position of endogenous and exogenous p27 are indicated. (B) Clones 14.1 and $14.8 \mathrm{grown}$ in the presence of $2 \mu \mathrm{g} / \mathrm{ml}$ of tetracycline were incubated for $18 \mathrm{hr}$ in medium containing the indicated concentrations of tetracycline. Total cell extracts $(5 \mu \mathrm{g}$ of protein) were subjected to Western immunoblotting with p27 antiserum (top). Other aliquots were immunoprecipitated with Cdk2 antibody, and the $\mathrm{Cdk} 2$-associated kinase activity was determined by use of histone $\mathrm{Hl}$ as a substrate. Phosphorylation reactions were subjected to SDS-PAGE and autoradiography (bottom). The phosphorylated histone $\mathrm{Hl}$ band is indicated (H1). (C) Cell cultures parallel to those described in $B$ were assayed in triplicate for [ ${ }^{125} \mathrm{I}$ ]deoxyuridine incorporation after $18 \mathrm{hr}$ of incubation with the indicated tetracycline concentrations. Data are averages \pm S.D. of triplicate determinations and are plotted as percent relative to the cpm incorporated in the presence of $2 \mu \mathrm{g} / \mathrm{ml}$ of tetracycline. The densitometric quantitation of the p27 band in $B$ and the PhosphorImager quantitation of the histone $\mathrm{Hl}{ }^{32} \mathrm{P}$ signal in $B$ are shown for comparison on the same graph. $(D)$ The Cdk2-associated $\mathrm{Hl}$ kinase activity is plotted against the relative levels of $\mathrm{p} 27$.

in proliferating $\mathrm{HaCaT}$ cells were 0.23 pmole $/ 10^{6}$ cells and $0.57 \mathrm{pmole} / 10^{6}$ cells, respectively, a lower molar ratio of $\mathrm{p} 27$ to Cdk2 than that observed in Mv1Lu cells. These observations suggested that the p27 pool displaced from Cdk4 and Cdk6 complexes in TGF- $\beta$-treated $\mathrm{HaCaT}$ cells played a limited role in the inhibition of $\mathrm{Cdk} 2$ in $\mathrm{HaCaT}$ cells.

In contrast to $\mathrm{Mv1Lu}$ cells, however, $\mathrm{HaCaT}$ cells underwent a rapid and marked increase in p2 ${ }^{\text {Cip } 1}$ mRNA levels in response to TGF- $\beta$ (Fig. 9A). This increase was followed by a progressive accumulation of $\mathrm{p} 21$ that reached a level that was 10 -fold over basal after $24 \mathrm{hr}$ with TGF- $\beta$ (Fig. 10E). This increase correlated with a corresponding increase in Cdk2-associated p21 (Fig. 10F) and with Cdk2 inhibition (see Fig. 2C).

TGF- $\beta$ elevated the expression of a luciferase reporter gene under the control of the human p 21 promoter, WWP-Luc (Fig. 9B). TGF- $\beta$ also activated expression of a similar promoter construct, DM-Luc (Fig. 9B), a construct that lacks the p53-responsive element (El-Deiry et al. 1993). The latter result and the presence of inactive p53 in HaCaT cells (Lehman et al. 1993) suggest that TGF- $\beta$ activates $\mathrm{p} 21$ transcription via a $\mathrm{p} 53$-independent mechanism in these cells. The TGF- $\beta$-induced increase in $\mathrm{p} 21$ expression may compensate for the limited availability of p27 in $\mathrm{HaCaT}$ cells and may cooperate with p15 to impose cell cycle arrest in these cells.

\section{Discussion}

The recent identification of two families of mammalian Cdk inhibitors represents an important step toward the elucidation of growth inhibitory mechanisms in which they participate. Here, we have examined the role of these inhibitors in the antiproliferative response to TGF- $\beta$ in MvlLu mink lung epithelial cells and HaCaT 

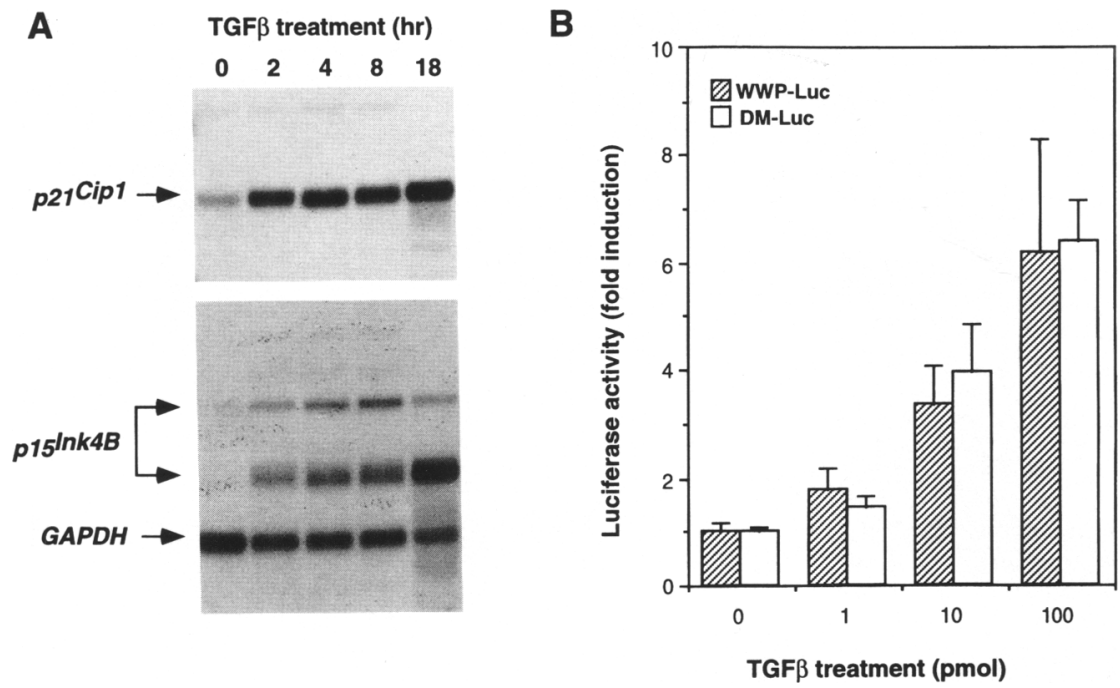

Figure 9. TGF- $\beta$ elevates p $21^{\text {Cip } 1}$ expres-
sion in HaCaT cells. $(A)$ Poly $\mid \mathrm{A})^{+}$RNA was
prepared from proliferating HaCaT cells
treated with 100 pM TGF- $\beta$ for the indi-
cated time. Northern blot analysis was per-
formed with a human p15 $5^{\text {Ink } 4 B}$ cDNA probe
and a GAPDH cDNA probe for control. The
same blot was reprobed with a p $21^{\text {Cip } 1}$
cDNA. (B) HaCaT cells were transiently
transfected with luciferase reporter genes
under the control of the p21 promoter,
which contains a p53 binding site (WWP-
Luc), or the same promoter region lacking
the p53-binding site (DM-Luc). The lu-
ciferase activity was measured after 24 hr of
treatment with the indicated picomolar
concentrations of TGF- $\beta$.

human keratinocytes. These two epithelial cell lines have been used extensively in previous studies to identify effects involved in the antiproliferative response to TGF- $\beta$. In both cell types, TGF- $\beta$ induces inhibition of $\mathrm{Rb}$ phosphorylation, down-regulation of $\mathrm{c}-\mathrm{myc}$, and $\mathrm{G}_{1}$ arrest (Laiho et al. 1990; Pietenpol et al. 1990; Howe et al. 1991; Zentella et al. 1991). However, previous attempts to explain these responses through effects on $G_{1}$ Cdks have not provided a unified model. TGF- $\beta$ has been reported variously to inhibit Cdk2 through $\mathrm{p} 27^{K i p 1}$ in MvlLu cells (Polyak et al. 1994a; Slingerland et al. 1994),

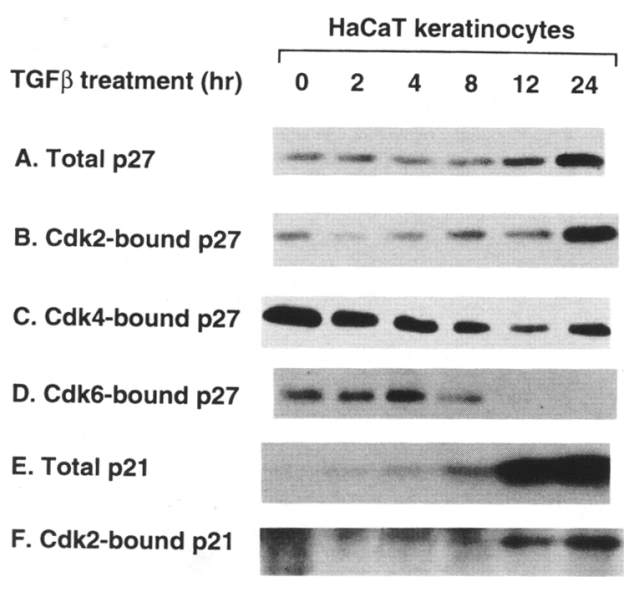

Figure 10. TGF- $\beta$ effects on the levels of $\mathrm{p} 21$ and $\mathrm{p} 27$ in $\mathrm{HaCaT}$ cells. Exponentially growing $\mathrm{HaCaT}$ cells were treated with TGF- $\beta$ for the indicated time. The levels of p27 $(A)$ and p21 $(E)$ were examined by the immunoblotting of total cell extracts 10.2 and $0.1 \mathrm{mg}$, respectively/ with the appropriate antibodies. The Cdk2-associated p27 $(B)$, Cdk4-associated p27 $|C|$, Cdk6-associated $\mathrm{p} 27(D)$, and Cdk2-associated $\mathrm{p} 21(F)$ were analyzed by immunoprecipitation with the appropriate antibody and Western immunoblotting with either $\mathrm{p} 27(B, C, D)$ or p21 antibody $(F)$. The amount of extracts used for the immunoprecipitations were $2 \mathrm{mg}(B), 5 \mathrm{mg}(C), 2.4 \mathrm{mg}(D)$, and $1 \mathrm{mg}(F)$. to inhibit Cdk4 synthesis in MvlLu cells by a p53-dependent mechanism (Ewen et al. 1993, 1995), to elevate p1 $5^{\text {Ink } 4 B}$ expression in $\mathrm{HaCaT}$ cells (Hannon and Beach 1994), and to decrease the levels of mRNAs encoding cyclin E, Cdk2, and Cdk4 (Geng et al. 1993; Slingerland et al. 1994).

Our present results suggest that these diverse effects represent separate aspects of a general mechanism (Fig. 11). Various elements of this model had been discussed previously. Our earlier results had shown that cyclin D-Cdk4 complexes can relieve inhibition of Cdk2 by p27 in vitro, suggesting that Cdk2 inhibition by p27 in vivo could likewise be modulated by the abundance of cyclin D-Cdk4 (Polyak et al. 1994a; Sherr and Roberts 1995). The possibility that induction of p15 might displace p27 from Cdk4 had also been raised previously (Peters 1994). Here, we provide experimental evidence that validates and extends these various aspects of a general model for Cdk inhibition by TGF- $\beta$ action. The resulting model suggests that TGF- $\beta$ inhibits $G_{1}$ Cdks through the cooperative action of Ink4 and Cip/Kip Cdk inhibitors. These events lead to cell cycle arrest, which is then followed by a decline in Cdk expression as cells accumulate in the quiescent state. The presence of high p27 levels in proliferating epithelial cells and the acute induction of p15 (and p21 in $\mathrm{HaCaT}$ cells) are the central features of this model.

\section{Retention of $p 27^{\mathrm{Kip} 1}$ expression in proliferating epithelial cells}

Resting $\mathrm{T}$ cells, macrophages, and fibroblasts contain high levels of p27 that decline when these cells are stimulated to enter the cell cycle (Kato et al. 1994a; Nourse et al. 1994). Inhibition of this decrease by rapamycin in $\mathrm{T}$ cells or cAMP agonists in macrophages prevents cell exit from quiescence (Kato et al. 1994a; Nourse et al. 1994). In contrast, MvlLu lung epithelial cells and human keratinocytes retain a high level of p27 in their prolifera- 
Figure 11. The proposed model for TGF- $\beta$ induced cell cycle arrest of epithelial cells via Cdk inhibitors. Exponentially growing epithelial cells contain p27 distributed in complexes with cyclin D-Cdk4, cyclin D-Cdk6, and cyclin E-Cdk2. TGF- $\beta$ addition causes a rapid elevation of p15, which binds to and inhibits Cdk4 and Cdk6, and displaces bound p27. In MvlLu lung epithelial cells, the displaced $\mathrm{p} 27$ binds to $\mathrm{Cdk} 2$ complexes leading to their inhibition. In $\mathrm{HaCaT}$ human keratinocytes the increase in p15 is accompanied by an increase in p21, which binds to and inhibits Cdk2. Thus, both cell lines are growth arrested via the combined action of an Ink4 inhibitor (p15) and a Cip/Kip inhibitor (p27 and/or p21). Following cell cycle arrest, Cdk expression declines as cells fall into the quiescent state. For purposes of clarity, Cdk6 is not depicted in the diagram.

tive state that is not markedly increased in response to TGF- $\beta$. What varies between these conditions is the proportion of $\mathrm{p} 27$ that is bound to its target Cdks. In quiescent MvlLu cells or in cells released from contact inhibition in the presence of TGF- $\beta$, p27 is in excess over Cdks, and some p27 is free (Polyak et al. 1994a). As cells enter the cell cycle, p27 is largely bound to heat-labile components and can be unmasked by heat treatment of cell extracts (Polyak et al. 1994a). By probing Cdk2, Cdk4, and Cdk6 immunoprecipitates with p27 antibodies, we show that p27 is associated with these proteins in proliferating cells. Furthermore, the pattern of p27-associated proteins, as cells enter $G_{1}$ phase, shows no evidence for $\mathrm{p} 27$ binding to a mitogen-induced sequestration factor. No changes in p27 phosphorylation are observed under these conditions. The abundance of p27 relative to its target Cdks, therefore, appears to be the main determinant of the state of p27 in the cell.

On the basis of quantitative immunoblotting results, the molar amount of $\mathrm{p} 27$ is close to that of Cdk2 in proliferating $\mathrm{MvlLu}$ cells and half that of $\mathrm{Cdk} 2$ in $\mathrm{HaCaT}$ cells. These levels of p27 are low enough to allow cell cycle progression but high enough to become a determining factor in the induction of cell cycle arrest by TGF- $\beta$. By use of an inducible p 27 expression system, we provide evidence that the p27 levels in proliferating MviLu cells are indeed close to the level that would cause cell cycle arrest. Remarkably, the results with this inducible system show that MvlLu cells cannot absorb more than a twofold increase in p27 levels without losing Cdk2 activity. A threefold increase in total p27 levels decreases by one-half the Cdk2 activity and the DNA synthesis rate, and about twice this amount of p27 causes an almost complete inhibition. These effects are observed under conditions in which various Cdks, not just Cdk2, participate in absorbing the increase in p27 levels. If other Cdks were not available for binding p27 in the cell, the amount of p27 needed to inhibit Cdk2 would be even lower. These observations suggest the existence of closely adjusted p 27 and Cdk levels, a point of particular relevance when the TGF- $\beta$ response is analyzed.
Early events in the TGF- $\beta$ response: $p 15^{\text {Ink4B }}$

induction and $\mathrm{p} 27^{\mathrm{Kipl}}$ transfer from Cdk4 and Cdk6 to Cdk2

TGF- $\beta$ addition at the time of MvlLu cell release from contact inhibition has been used extensively to study the antimitogenic action of this factor. TGF- $\beta$ addition under these conditions prevents $\mathrm{Cdk} 4$ accumulation (Ewen et al. 1993) with p27 levels remaining in excess over Cdk2 levels and impeding Cdk2 activation by Cak (Polyak et al. 1994a). In essence, TGF- $\beta$ addition aborts cell exit from quiescence by maintaining the conditions that prevail in the contact-inhibited state. However, these are artificial conditions in which the cell is faced with one proliferative constraint while being released from another. It seems more likely that as a physiological regulator of epithelial tissue homeostasis TGF- $\beta$ would act by limiting the expansion of actively proliferating cell populations. Therefore, we investigated the effect of TGF- $\beta$ on proliferating cells.

TGF- $\beta$ addition to exponentially proliferating Mv1Lu epithelial cells inhibits Cdk2 kinase activity and causes cell cycle arrest before appreciably decreasing the levels of Cdk2, Cdk4, Cdk6, or cyclins E, DI, or A. Under these conditions, the loss of Cdk2 activity correlates with a marked (four- to sixfold) increase in p27 binding to Cdk2. According to the results from our p27-inducible system, such an increase in bound p27 can account for the observed inhibition of Cdk2 by TGF- $\beta$. Loss of the Cakphosphorylated, fast-migrating form of Cdk2 is not observed until several hours after Cdk2 inhibition, a phenomenon consistent with the ability of p27 not only to prevent Cdk2 phosphorylation by Cak but also to inhibit activated cyclin-Cdk2 complexes (Polyak et al. 1994b; Toyoshima and Hunter 1994).

If there is no free $\mathrm{p} 27$ in proliferating Mv1Lu cells and if TGF- $\beta$ causes neither a rise in p27 levels nor a decline in Cdk4 or Cdk6 levels, how then is Cdk2-bound p27 increased in these cells? We observed that this increase is preceded by a release of $\mathrm{p} 27$ from complexes with Cdk4 and Cdk6. Furthermore, the TGF- $\beta$-induced changes in p27 binding to Cdk4, Cdk6, and Cdk2 in 
MvlLu cells correlate with a marked increase in p15 ${ }^{\text {Ink4B }}$ expression similar to that described previously in HaCaT keratinocytes (Hannon and Beach 1994). Because Ink 4 protein binding to Cdk4 and Cdk6 in vivo appears to prevent association of these Cdks with type $\mathrm{D}$ cyclins (Serrano et al. 1993; Guan et al. 1994; Chan et al. 1995; Hirai et al. 1995), the TGF- $\beta$-induced increase in p15 levels is the probable cause of $\mathrm{p} 27$ release from these Cdks. Two additional observations support this conclusion. First, p15 overexpression in MvlLu cells causes a loss in Cdk4-bound p27 and a gain in Cdk2-bound p27. Second, addition of excess recombinant pl5 decreases p27 binding to cyclin D-Cdk4 complexes in vitro. To observe this effect, p15 had to be added before p27, suggesting that p15 must interact with and/or dissociate the cyclin D-Cdk4 complex in order to inhibit p27 binding to this complex in vitro. Although the mechanisms underlying these p15-induced p 27 transfers in vivo and in vitro are poorly understood at this point, our preliminary results suggest that 15 is involved in the TGF- $\beta$ effect. It is possible that when p15 is induced, complexes between cyclin D, Cdk4, and p 15 could initially form. Because cyclin $\mathrm{D}$ has a very short half life, such ternary complexes would be expected to yield Cdk4-p15 complexes, preventing the assembly of new cyclin D-Cdk4 complexes as well as inhibiting Cdk4 kinase activity. It will be important to experimentally address these possibilities to understand the mechanism by which p15 causes the release of Cdk4-bound p27.

\section{p21 ${ }^{\mathrm{Cip} 1}$ induction potentiates Cdk2 inhibition in $\mathrm{HaCaT}$ cells}

The TGF- $\beta$ response in $\mathrm{HaCaT}$ cells is in many ways similar to that in MvlLu cells. Both cell lines arrest in $G_{1}$ phase without an immediate loss of $G_{1}$ Cdks or an immediate increase in p27 levels. Both cell lines show a rapid increase in p15 expression and a concomitant dissociation of $\mathrm{p} 27$ from cyclin D-dependent kinases. However, a significant difference is that $\mathrm{HaCaT}$ cells show a rapid and marked increase in p21 mRNA levels that is not observed in MvlLu cells. This effect is mediated by a p53-independent transcriptional event and is followed by a significant elevation in $\mathrm{p} 21$ levels and $\mathrm{p} 21$ association with Cdk2. The levels of p27 in $\mathrm{HaCaT}$ cells are somewhat lower than in MvlLu cells. The lower levels of p27 in combination with the elevation of p21 may explain the limited increase in Cdk2-bound p27 observed in TGF- $\beta$-treated $\mathrm{HaCaT}$ cells. While representing an interesting difference in the TGF- $\beta$ response pattem of these two cell lines, an elevation of p21 expression conforms to a general scheme whereby TGF- $\beta$ action targets $\mathrm{Cdk} 4 / \mathrm{Cdk} 6$ by induction of an Ink 4 family member and Cdk2 by transfer and/or induction of a Cip/Kip family member.

\section{Cell cycle arrest and adaptation to quiescence}

The TGF- $\beta$-induced elevation and redistribution of Cdk inhibitors are followed by a decrease in Cdk2 and Cdk4 levels and, in some cases, a small increase in p27 levels. This second set of events start when a large portion of the cell population has already become growth arrested, suggesting that they represent a process of adaptation to the quiescent state. The temporal separation between these two sets of events is clear in MvlLu cells but less obvious in keratinocytes. This discrepancy could result from the observed differences in cell cycle length and distribution of these two cell lines. Interestingly, low levels of Cdk2 and Cdk4 and high levels of p27 are also present in contact-inhibited cells, suggesting that these changes may occur irrespective of the type of signal causing the cell cycle arrest.

An involvement of $\mathrm{p} 53$ in $\mathrm{Cdk} 4$ down-regulation by TGF- $\beta$ has been suggested in Mv1Lu cells (Ewen et al. 1995). This may not be a general phenomenon, however, because $\mathrm{HaCaT}$ cells contain inactivating mutations in p53 (Lehman et al. 1993) and still show Cdk4 downregulation as a late TGF- $\beta$ response. On the other hand, Cdk 4 down-regulation by TGF- $\beta$ is not faster in primary keratinocytes, which have wild-type $\mathrm{p} 53$, than in $\mathrm{HaCaT}$ keratinocytes. Overexpression of Cdk4 in MvlLu cells can confer resistance to growth inhibition by TGF- $\beta$, whereas overexpression of Cdk2 cannot (Ewen et al. 1993). It is conceivable that overexpression of Cdk4 acts by providing a larger sink for both p15 and p27, effectively protecting various $G_{1}$ Cdks from these inhibitors. In contrast, overexpression of Cdk2 would provide a large sink for $\mathrm{p} 27$ but not $\mathrm{p} 15$, and thus would not protect Cdk4 from a TGF- $\beta$-induced surge in p15 levels, leading to growth arrest.

$\mathrm{Cdk} 2$ and $\mathrm{Cdk} 4 / 6$ are both rate limiting for $\mathrm{G}_{1}$ progression and $S$ phase onset (Ohtsubo and Roberts 1993; Quelle et al. 1993; Sherr and Roberts 1995). Phosphorylation of $\mathrm{Rb}$ by cyclin $\mathrm{D}-\mathrm{Cdk} 4 / 6$ and phosphorylation of as yet unknown substrates by cyclin E-Cdk2 are thought to allow passage through the restriction point at which the cell becomes committed to completing the division cycle without requiring further mitogenic stimulation. An antiproliferative scheme based on the concerted action of p15 and p27 (or p21) on these Cdks might be optimal for an orderly withdrawal from the cell cycle in response to TGF- $\beta$ in epithelial cells.

\section{Materials and methods}

\section{Cell culture and transfection}

Mv1Lu mink lung epithelial cells (ATCC, CLL64) and R-1B/ L17, a subclone of Mv1Lu (Boyd and Massagué 1989) were grown in minimal essential medium containing nonessential amino acids supplemented with $10 \%$ fetal bovine serum (FBS, GIBCO, BRL). For cell release from contact-inhibition experiments, MvlLu cells were cultured to confluency in the presence of $10 \%$ FBS, and released from contact inhibition by trypsinization and reseeding in sparse conditions. Human recombinant TGF- $\beta 1$ (100 pM: R\&D System) was added to the cells at the indicated times. Cell entry into $S$ phase was routinely confirmed by measurement of $\left[{ }^{125} \mathrm{I}\right]$ deoxyuridine incorporation into DNA (Laiho et al. 1990). HaCaT keratinocytes (a gift from Dr. Norbert Fusenig, EMBO Labs, Heidelberg, Germanyl were 
maintained in DME medium supplemented with $10 \%$ FBS. Primary human foreskin keratinocytes (a gift from Lisa StaianoCoico, Cornell Medical College, N.Y.) were grown in Keratinocyte-SFM medium (GIBCO, BRL) with supplements (EGF and $\mathrm{BPE}$ ) and were used for experiments at passage number four.

$\mathrm{R}-1 \mathrm{~B} / \mathrm{L} 17$ cells were transiently transfected with $\mathrm{pCMV} 5$ vector or pCMV5-p15, encoding human p1 $5^{\text {Ink } 4 B}$, by use of the DEAE-dextran transfection method as described previously (Attisano et al. 1993). A cDNA fragment encoding the full-length human p15 was amplified by PCR (Hannon and Beach 1994) with primers flanking the p15-coding sequence. The amplified fragment was cloned into the HindIII-XbaI site of pCMV5 and verified by sequence analysis. The DEAE-dextran method was utilized to transfect $\mathrm{HaCaT}$ keratinocytes with the luciferase reporter constructs WWP-Luc and DM-Luc, which contain, respectively, a p21 promoter region or the same region lacking a p53-binding site (El-Deiry et al. 1993).

\section{Metabolic labeling}

Cell cultures were incubated for $30 \mathrm{~min}$ in methionine-free medium supplemented with $10 \%$ dialyzed fetal bovine serum, followed by incubation for $1-4 \mathrm{hr}$ in the same medium with 200 $\mu \mathrm{Ci} / \mathrm{ml}$ of $\left[{ }^{35} \mathrm{~S}\right]$ methionine (Trans ${ }^{35} \mathrm{~S}$ label, ICN) or $\left[{ }^{35} \mathrm{~S}\right.$ )methionine and $\left[{ }^{35} \mathrm{~S}\right]$ cysteine. Subsequently, the cells were collected by trypsinization and centrifuged at $2,000 \mathrm{~g}$ for $5 \mathrm{~min}$. Cell pellets were lysed by sonication in hypotonic buffer $150 \mathrm{mM}$ HEPES at $\mathrm{pH} 7.4,50 \mathrm{~mm} \mathrm{KCl}, 0.3 \mathrm{~mm} \mathrm{Na}$-orthovanadate, $50 \mathrm{mM} \mathrm{NaF}, 80$ $\mu \mathrm{M} \beta$-glycerophosphate, $20 \mathrm{~mm} \mathrm{Na}$ pyrophosphate, $1 \mathrm{mM}$ DTT, $1 \mathrm{mM}$ PMSF, $10 \mu \mathrm{g} / \mathrm{ml}$ of leupeptin, $10 \mu \mathrm{g} / \mathrm{ml}$ of antipain, 100 $\mu \mathrm{g} / \mathrm{ml}$ of benzamidine hydrochloride, $5 \mu \mathrm{g} / \mathrm{ml}$ of aprotinin, and $100 \mu \mathrm{g} / \mathrm{ml}$ of soybean trypsin inhibitor), and lysates were clarified by centrifugation $\left(10,000 \mathrm{~g}\right.$ for $20 \mathrm{~min}$ at $\left.4^{\circ} \mathrm{C}\right)$.

For in vivo labeling with ${ }^{32} \mathrm{P}$, the cells were preincubated for $30 \mathrm{~min}$ in phosphate-free medium supplemented with $10 \%$ dialyzed fetal bovine serum, followed by incubation in the same medium with $1 \mathrm{mCi} / \mathrm{ml}\left[{ }^{32} \mathrm{P}\right]$ orthophosphate (NEN) for $2 \mathrm{hr}$. Cell extracts were prepared as described for $\left[{ }^{35} \mathrm{~S} \mid\right.$ methionine labeling.

\section{Antibodies, immunoprecipitation, and immunoblot analyses}

Antibodies against $\mathrm{p} 27^{\mathrm{Kip} 1}$ were raised by immunization of rabbits with the full-length recombinant mouse $\mathrm{p} 27^{\text {Kip } 1}$, which is $\sim 90 \%$ identical to the human and mink sequences (Polyak et al. 1994b). The p27 protein was purified to homogeneity by binding to nickel/NTA/agarose (Qiagen) through a hexahistidine sequence attached to its carboxyl terminus (Polyak et al. 1994b). Injections were performed according to standard protocols (Harlow and Lane 1988); the titer of the bleeds was determined by immunoblot and immunoprecipitation analysis. Western immunoblotting of recombinant p27 fragments indicated that these antibodies recognize the carboxy-terminal half of p27 but not the cyclin-Cdk-binding domain (amino acids 28-79; Polyak et al. 1994b/ present in its amino-terminal half. Because the amino-terminal cyclin-cdk-binding domain contains most of the sequence similarity with other family members (Lee et al. 1995), the antibodies are specific for $\mathrm{p} 27$.

Antibodies against the $\mathrm{Cdk} 2$ and $\mathrm{Cdk} 4$ proteins were a generous gift from J. Kato and C.J. Sherr (St. Jude Children's Research Hospital, Memphis, TN) or were obtained from either Pharmingen or Santa Cruz Biotechnology. The antibody against Cdk6 was generously provided by $M$. Meyerson and E. Harlow (Meyerson and Harlow 1994) or obtained from Santa Cruz, Biotechnology. Cdk2 immunoprecipitations and Western immunoblots were done with an anti-Cdk2 antibody against a peptide from the carboxyl terminus of Cdk2 (CDVTKPVPHLRL; Pharmingen). Cdk4 immunoprecipitations and Western immunoblots in Figures 1 and 3 were done with Cdk4 antibody Ry (Matsushime et al. 1992, 1994). Anti-Cdk4 antibody from Santa Cruz Biotechnology (epitope from amino acids 282-303) was used for the immunoprecipitations described in Figures 7 and 8 . For all other immunoprecipitations and Western immunoblots anti-Cdk4 antibody from Pharmingen (cat. no. 14936E) was used. p1 $5^{\text {Ink4B}}$ immunoblots were done with antibody against the carboxyl terminus of the human protein (Santa Cruz Biotechnology). The $\mathrm{p} 21^{\mathrm{Cip} 1}$ antibodies were from Pharmingen.

For immunoprecipitations, precleared cell lysates in LSLD buffer ( $50 \mathrm{~mm}$ HEPES at $\mathrm{pH} 7.4,50 \mathrm{~mm} \mathrm{NaCl}, 10 \%$ glycerol, $0.1 \%$ Tween $20,0.3 \mathrm{~mm}$ Na-orthovanadate, $50 \mathrm{~mm} \mathrm{NaF}, 80 \mu \mathrm{M}$ $\beta$-glycerophosphate, $20 \mathrm{~mm}$ Na-pyrophosphate, $1 \mathrm{~mm}$ DTT and $1 \mathrm{mM}$ PMSF, $10 \mu \mathrm{g} / \mathrm{ml}$ of leupeptin, $10 \mu \mathrm{g} / \mathrm{ml}$ of antipain, 100 $\mu \mathrm{g} / \mathrm{ml}$ of benzamidine hydrochloride, $5 \mu \mathrm{g} / \mathrm{ml}$ of aprotinin, and $100 \mu \mathrm{g} / \mathrm{ml}$ of soybean trypsin inhibitor) were incubated with the indicated antibody for $1-2 \mathrm{hr}$ at $4^{\circ} \mathrm{C}$ with gentle agitation. Immunocomplexes bound to protein A-Sepharose were collected by centrifugation and washed several times in LSLD buffer. Immunoprecipitated proteins were resolved by $12 \%$ SDS-PAGE followed by fluorography $\left({ }^{35} \mathrm{~S}\right.$-labeled proteins) and autoradiography.

For immunoblot analysis, total cell extracts or immunoprecipitates were resolved by $12 \%$ SDS-PAGE $(15 \%$ in the case of p15), and transferred to PVDF (Immobilon; Millipore) membranes. Immunoblots were developed by use of ECL (Amersham) according to the manufacturer's instructions. In the case of immunoblots performed after immunoprecipitations, protein A-conjugated horseradish peroxidase (Sigma) was used instead of a secondary antibody to avoid binding to immunoglobulin light chains.

\section{Northern blot assays}

Total RNA from Mv1Lu or $\mathrm{HaCaT}$ cells in various proliferative states, as described in the text, was prepared by RNAzol B (BIOTECX LAB) and enriched for poly $(A)^{+}$RNA by use of PolyATtract mRNA Isolation System III (Promega). Poly(A) ${ }^{+}$ RNA was resolved on 1\% MOPS-formaldehyde gels and transferred to Duralon ${ }^{\text {UV }}$ membranes (Stratagene) by Posiblot (Stratagene). Northern blots to measure mink p1 $5^{\text {Ink4B }}$ mRNA were done with a cDNA probe corresponding to the first exon of human pl5 $5^{\text {Ink4B }}$ (Guan et al. 1994; Hannon and Beach 1994). To obtain the mink p15 sequence, total RNA was prepared from MvlLu cells treated with TGF- $\beta$ for $8 \mathrm{hr}$. Poly $(A)^{+}$RNA was purified and reverse transcribed with SuperScript RNase $\mathrm{H}^{-}$ Reverse Transcriptase (GIBCO, BRL). The cDNA obtained from that reaction was amplified with a 5 primer corresponding to nucleotides 4-24 and a 3 primer corresponding to nucleotides 115-136 in the human p15 sequence. The size of the amplified mink DNA fragment (132 bp) was the same as the DNA fragment from HaCaT cells amplified with these two primers. The blunt-end mink p15 DNA fragment was cloned into pCR II (Invitrogen) by use of the TA Cloning Kit (Invitrogen). The mink p15 probes were labeled to high specific activity by PCR with [ $\left.{ }^{32} \mathrm{P}\right] \mathrm{dCTP}$ (NEN), pCR II-mink pl5, and the oligonucleotides described. Northern blot hybridization of HaCaT cells was performed with a human p15 probe corresponding to nucleotides 4-136 labeled to high specific activity by PCR with [32 P]dCTP and the above-mentioned primers. The same blot was stripped and reprobed with a full-length human $\mathrm{p} 21^{32} \mathrm{P}$-cDNA probe. To control for loading, the Northern blots were probed with the housekeeping gene glyceraldehyde-3-phosphate dehydrogenase (GAPDH). 
In vitro complex formation between cyclin D-Cdk4, p27, and $p 15$

Hi5 (Pharmingen) insect cells were coinfected with recombinant baculoviruses expressing cyclin D2 and Cdk4. Baculoviral cell extracts were prepared as described (Desai et al. 1992). p27 in pCITE2a (Novagen) was transcribed and translated with Red Nova lysate (Novagen) in the presence of $\left[{ }^{35} S \mid\right.$ methionine following the manufacturer's instructions. A cDNA fragment encoding the full-length human p15 was amplified by PCR (Hannon and Beach 1994) with primers flanking the p15 coding sequence. The amplified fragment was cloned into the NheI-XhoI site of the $T 7$ overexpression vector $\mathrm{pET} 21 \mathrm{a}|+|$. The construct was modified to encode p 15 with a carboxy-terminal hexahistidine sequence and was verified by sequence analysis. p15 was expressed in BL21(DE3) pLysS bacteria induced with IPTG and purified by affinity chromatography on nickel NTA-agarose as described for p27 (Polyak et al. 1994b) but at $4^{\circ} \mathrm{C}$. The binding assay was performed by the mixing of the insect cell lysate containing the cyclin $\mathrm{D} 2-\mathrm{Cdk} 4$ with purified recombinant $\mathrm{p} 15$ and incubation on ice for $30 \mathrm{~min}$ in LSLD buffer in a total volume of $100 \mu \mathrm{l}$. Following addition of $30 \mathrm{ng}$ of in vitro-translated $\mathrm{p} 27$, the incubation continued for another $30 \mathrm{~min}$. Cdk4 and the associated proteins were immunoprecipitated by bringing of the volume to $500 \mu \mathrm{l}$ with LSLD buffer and addition of antibody against the carboxyl terminus of $\mathrm{Cdk} 4$ and protein A-Sepharose for $1 \mathrm{hr}$ at $4^{\circ} \mathrm{C}$. The complexes were washed twice in $1 \mathrm{ml}$ of cold LSLD buffer followed by $12 \%$ SDS-PAGE and fluorography. p27 associated with cyclin D-Cdk4 was quantitated on a PhosphorImager.

\section{Inducible p27 expression system}

The plasmid pUHD15-1 encodes a gene expressing the bacterial tetracycline repressor fused to the activating domain of herpes simplex virus (HSV) VP16, tTA. pUHD15-1 neo was constructed by insertion of the pREP9 fragment NotI (nucleotide 669)-NruI (nucleotide 3556) encoding the neomycin resistant gene into the XhoI site of pUHDl5-1 (Gossen and Bujard 1992). The pUHD10-3 hygromycin vector was generated by insertion of the hygromycin-encoding fragment Bam HI (nucleotide 947)-NruI (nucleotide 3207) from pMEP4 into the XhoI site of pUHD10-3. The plasmids pUHD10-3 and pUHC13-3 carry a multiple cloning site and a luciferase gene, respectively, downstream of a promoter that contains regulatory elements from the tetracycline operon (Gossen and Bujard 1992). Therefore, expression from the promoter is dependent on the presence of the tTA. The KpnI-BamHI fragment from pCMV5-p27.HA encoding fulllength murine $\mathrm{p} 27$ with a carboxy-terminal HA tag was inserted into the $X b a I$ site in pUHD10-3 hygromycin to create pUHD10-3 hygromycin-p27.HA.

MvlLu cells were transfected with $25 \mu \mathrm{g}$ of pUHD15-1neo by use of the lipofectin procedure according to the manufacturer's protocol (GIBCO, BRL). Clones were selected in $1 \mathrm{mg} / \mathrm{ml}$ of G-418 (Geneticin, GIBCO, BRL). Then, they were transiently transfected with pUHC13-3 to test their ability to induce or repress luciferase activity in the absence or presence of $2 \mu \mathrm{g} / \mathrm{ml}$ tetracycline, respectively. Fifteen percent of the clones had high luciferase activity that was at least 100 -fold repressible in the presence of tetracycline. On the basis of this criterium, a clone was chosen for the second round of transfection, which was performed with $25 \mu \mathrm{g}$ of pUHD10-3 hygromycin p27.HA. Clones were selected in $1 \mathrm{mg} / \mathrm{ml} \mathrm{G}-418,0.3 \mathrm{mg} / \mathrm{ml}$ of hygromycin (Calbiochem), and $2 \mu \mathrm{g} / \mathrm{ml}$ of tetracycline. To examine the expression of $\mathrm{p} 27$, the clones were grown to $80 \%$ confluency. The culture medium was then switched to medium alone or medium containing $2 \mu \mathrm{g} / \mathrm{ml}$ of tetracycline. After 18 $\mathrm{hr}$, the cells were lysed in hypotonic buffer $20 \mathrm{~mm}$ HEPES at $\mathrm{pH}$ $7.4,5 \mathrm{mM} \mathrm{KCl}, 0.5 \mathrm{~mm} \mathrm{MgCl} 2,1 \mathrm{mM}$ PMSF, $1 \mathrm{mM}$ DTT, 10 $\mu \mathrm{g} / \mathrm{ml}$ of leupeptin, $10 \mu \mathrm{g} / \mathrm{ml}$ of antipain, $100 \mu \mathrm{g} / \mathrm{ml}$ of benzamidine hydrochloride, $5 \mu \mathrm{g} / \mathrm{ml}$ of aprotinin, and $100 \mu \mathrm{g} / \mathrm{ml}$ of soybean trypsin inhibitor), sonicated for $1 \mathrm{~min}$ and centrifuged at $14,000 \mathrm{rpm}$ for $5 \mathrm{~min}$ at $4^{\circ} \mathrm{C}$. Whole-cell extract $(10 \mu \mathrm{g})$ was run on $12 \%$ SDS-PAGE and probed by Western immunoblotting with anti $\mathrm{p} 27$ serum. Of 20 clones analyzed, 2 were found (clones 14.5 and 14.8) that expressed p27 in the absence of tetracycline. A clone, 14.1, that does not express p27 in the absence of tetracycline was chosen as a negative control. Growth inhibition assays were performed as previously described (Laiho et al. 1990) except the cells were fed medium containing varying concentrations of tetracycline as indicated. To analyze p27 expression and its interaction with cyclin-Cdk complexes, cells were seeded at a concentration of $4 \times 10^{6}$ cells per 150-mm dish /to match the density of the cells in the growth inhibition assays!. After $3 \mathrm{hr}$, the cell culture medium was replaced with medium containing varying concentrations of tetracycline as indicated. After $18 \mathrm{hr}$ the cells were harvested. Alternatively, the medium containing $2 \mu \mathrm{g} / \mathrm{ml}$ of tetracycline was replaced with medium containing no tetracycline (time 0 ), and the cells were harvested 6 or $24 \mathrm{hr}$ later. Harvested cells were lysed in hypotonic buffer containing protease inhibitors as described above. p27 levels were determined by running of $5 \mu \mathrm{g}$ per lane of whole-cell extracts on a $12 \%$ SDS-PAGE and probing the western immunoblots with anti-p27 serum. Cdk-bound p27 complexes were analyzed by immunoprecipitation of the cell extracts with either anti-Cdk2 or anti-Cdk4 antibodies, followed by $12 \%$ SDS-PAGE and Western immunoblotting.

\section{Cdk2 and p27 quantitation in Mv1Lu and HaCaT cells}

To quantitate the levels of Cdk2 and p27, extracts were made from exponentially growing $\mathrm{MvlLu}$ and $\mathrm{HaCaT}$ cells as described above. Extracts ranging in concentration from 5-200 ng of total protein per lane were examined on $12 \%$ SDS-PAGE. Standard concentration curves (5-500 ng per lane) of either Cdk2 or p27 were run in parallel on each gel. Human recombinant Cdk2 was produced in insect cells and purified to homogeneity. p27 was expressed in BL21(DE3) pLysS bacteria induced with IPTG and purified by affinity chromatography on nickel NTA-agarose as described (Polyak et al. 1994b). Western immunoblots were analyzed by blotting with either anti-Cdk2 or antip27 antibodies.

\section{Other methods}

V8 peptide mapping of immunoprecipitated p27 (Polyak et al. 1994b), phosphoamino acid analysis (Boyle et al. 1991) and in vitro kinase assays of Cdk2 immunoprecipitates (Koff et al. 1993; Polyak et al. 1994a) were performed as described previously.

Cells were prepared for flow cytometry analysis as described (Polyak et al. 1994b). The propidium iodide stained cells were analyzed by FACScan (Becton Dickinson) and Multicycle software (PHOENIX Flow Systems).

\section{Acknowledgments}

We thank J. Kato, C. Sherr, M. Meyerson, and E. Harlow for generously providing Cdk reagents, G. Hannon and D. Beach for human p15 cDNA, L. Staiano-Coico for human primary keratinocytes, $H$. Bujard and M. Gossen for tetracycline system vec- 
tors, B. Vogelstein for $\mathrm{p} 21$ promoter constructs, and T. Delohery for flow cytometry assays. This work was supported by $\mathrm{Na}$ tional Institute of Health grant to Memorial Sloan-Kettering Cancer Center. K.P. is the recipient of a Frank L. Horsfall Jr. predoctoral fellowship. A.I. is the recipient of a Physician Postdoctoral fellowship from the Howard Hughes Medical Institute. I.R. and J.M. are respectively a Research Associate and an Investigator of the Howard Hughes Medical Institute.

The publication costs of this article were defrayed in part by payment of page charges. This article must therefore be hereby marked "advertisement" in accordance with 18 USC section 1734 solely to indicate this fact.

\section{References}

Attisano, L., J. Cárcamo, F. Ventura, F.M.B. Weis, J. Massagué, and J.L. Wrana. 1993. Identification of human activin and TGF- $\beta$ type I receptors that form heteromeric kinase complexes with type II receptors. Cell 75: 671-680.

Boukamp, P., R.T. Petrussevska, D. Breitkreutz, J. Hornung, A. Markham, and N.E. Fusenig. 1988. Normal keratinization in a spontaneously immortalized aneuploid human keratinocyte cell line. J. Cell Biol. 106: 761-771.

Boyd, F.T. and J. Massagué. 1989. Growth inhibitory response to transforming growth factor- $\beta$ linked to expression of a 53 $\mathrm{kDa}$ cell surface TGF- $\beta$ receptor. I. Biol. Chem. 274: 22722278.

Boyle, W.J., P. van der Geer, and T. Hunter. 1991. Phosphopeptide mapping and phosphoamino acid analysis by two-dimensional separation on thin-layer cellulose plates. Methods Enzymol. 201B: 110-149.

Caldas, C., S.A. Hahn, L.T. da Costa, M.S. Redston, M. Schutte, A.B. Seymour, C.L. Weinstein, R.H. Hruban, C.J. Yeo, and S.E. Kern. 1994. Frequent somatic mutations and homozygous deletions of the p16 (MTS1) gene in pancreatic adenocarcinoma. Nature Genet. 8: 27-32.

Chan, F.K.M., J. Zhang, L. Cheng, D.N. Shapiro, and A. Winoto. 1995. Identification of human and mouse p19, a novel CDK4 and CDK6 inhibitor with homology to p16 $6^{\text {ink4 }}$. Mol. Cell. Biol. 15: 2682-2688.

Chen, J., P.K. Jackson, M.W. Kirschner, and A. Dutta. 1995. Separate domains of $\mathrm{p} 21$ involved in the inhibition of Cdk kinase and PCNA. Nature 374: 386-388.

Desai, D., Y. Gu, and D.O. Morgan. 1992. Activation of human cyclin-dependent kinases in vitro. Mol. Biol. Cell 3: 571582.

Elbendary, A., A. Berchuck, P. Davis, L. Havrilesky, R.C. Bast Jr., J.D. Iglehart, and J.R. Marks. 1994. Transforming growth factor $\beta 1$ can induce CIPl/WAFl expression independent of the p53 pathway in ovarian cancer cells. Cell Growth Differ. 5: 1301-1307.

El-Deiry, W.S., T. Tokino, V.E. Velculescu, D.B. Levy, R. Parsons, J.M. Trent, D. Lin, E. Mercer, K.W. Kinzler, and B. Vogelstein. 1993. WAF1, a potential mediator of p53 tumor suppression. Cell 75: 817-825.

El-Deiry, W.S., J.W. Harper, P.M. O'Connor, V.E. Velculescu, C.E. Canman, J. Jackman, J.A. Pietenpol, M. Burrell, D.E. Hill, Y. Wang, K.G. Wiman, W.E. Mercer, M.B. Kastan, K.W. Kohn, S.J. Elledge, K.W. Kinzler, and B. Vogelstein. 1994. WAF1/CIP1 is induced in p53-mediated G1 arrest and apoptosis. Cancer Res. 54: 1169-1174.

Ewen, M.E., H.K. Sluss, L.L. Whitehouse, and D.M. Livingston. 1993. TGF- $\beta$ inhibition of Cdk4 synthesis is linked to cell cycle arrest. Cell 74: 1009-1020.

Ewen, M.E., C.J. Oliver, H.K. Sluss, S.J. Miller, and D.S. Peeper.
1995. p53-dependent repression of CDK4 translation in TGF- $\beta$-induced $G_{1}$ cell cycle arrest. Genes \& Dev. 9: 204 217.

Flores-Rozas, H., Z. Kelman, F.B. Dean, Z.-Q. Pan, J.W. Harper, S.J. Elledge, M. O'Donnel, and J. Hurwitz. 1994. Cdk-interacting protein 1 directly binds with proliferating cell nuclear antigen and inhibits DNA replication catalyzed by the DNA polymerase $\delta$ holoenzyme. Proc. Natl. Acad. Sci. 91: 86558659.

Geng, Y. and R.A. Weinberg. 1993. Transforming growth factor $\boldsymbol{\beta}$ effects on expression of $\mathrm{G} 1$ cyclins and cyclin-dependent protein kinases. Proc. Natl. Acad. Sci. 90: 10315-10319.

Gossen, M. and H. Bujard. 1992. Tight control of gene expression in mammalian cells by tetracycline-responsive promoters. Proc. Natl. Acad. Sci. 89: 5547-5551.

Gu, Y., C.W. Turck, and D.O. Morgan. 1993. Inhibition of CDK2 activity in vivo by an associated $20 \mathrm{~K}$ regulatory subunit. Nature 366: 707-710.

Guan, K.-L., C.W. Jenkins, Y. Li, M.A. Nichols, X. Wu, C.L. O'Keefe, A.G. Matera, and Y. Xiong. 1994. Growth suppression by $\mathrm{pl} 8$, a p16 $6^{\mathrm{INK} 4 / \mathrm{MTS} 1}$ and $\mathrm{p} 14^{\mathrm{INK} 4 / \mathrm{MTS} 2}$-related CDK6 inhibitor, correlates with wild-type pRb function. Genes \& Dev. 8: 2939-2952.

Hannon, G.J. and D. Beach. 1994. p15 $5^{\text {INK4B }}$ is a potential effector of TGF- $\beta$-induced cell cycle arrest. Nature 371: 257-261.

Harlow, E. and D. Lane. 1988. Antibodies: A laboratory handbook. Cold Spring Harbor Laboratory, Cold Spring Harbor, New York.

Harper, J.W., G.R. Adami, N. Wei, K. Keyomarsi, and S.J. Elledge. 1993. The p2l cdk-interacting protein Cip1 is a potent inhibitor of $\mathrm{G}_{1}$ cyclin-dependent kinases. Cell 75: 805816.

Havely, O., B.G. Novitch, D.B. Spicer, S.X. Skapek, J. Rhee, G.J. Hannon, D. Beach, and A. Lassar. 1995. Correlation of terminal cel cycle arrest of skeletal muscle with induction of p21 by MyoD. Science 267: 1018-1021.

Hirai, H., M.F. Roussel, J.-Y. Kato, R.A. Ashmun, and C.J. Sherr. 1995. Novel Ink4 proteins, p19 and p18, are specific inhibitors of the cyclin D-dependent kinases CDK4 and CDK6. Mol. Cell. Biol. 15: 2672-2681.

Howe, P.H., G. Draetta, and E.B. Leof. 1991. Transforming growth factor $\beta 1$ inhibition of $\mathrm{p} 34 \mathrm{cdc} 2$ phosphorylation and histone $\mathrm{Hl}$ kinase activity is associated with Gl/S-phase growth arrest. Mol. Cell. Biol. 11: 1185-1194.

Hunter, T. and J. Pines. 1994. Cylins and cancer II: Cyclin D and CDK inhibitiors come of age. Cell 79: 573-582.

Kamb, A., N.A. Gruis, J. Weaver-Feldhaus, Q. Liu, K. Harshman, S.V. Tavtigian, E. Stockert, R.S. Day III, B.E. Johnson, and M.H. Skolnick. 1994. A cell cycle regulator potentially involved in genesis of many tumor types. Science 264: 436440.

Kato, J., M. Matsuoka, K. Polyak, J. Massagué, and C.J. Sherr. 1994a. Cyclic AMP-induced Gl phase arrest mediated by an inhibitor $\left(\mathrm{p} 27^{\mathrm{Kipl}}\right)$ of cyclin-dependent kinase-4 activation. Cell 79: 487-496.

Kato, J-Y., M. Matsuoka, D.K. Strom, C.J. Sherr. 1994b. Regulation of cyclin D-dependent kinase 4 (cdk4) by cdk4-activating kinase. Mol. Cell. Biol. 14: 2713-2721.

Koff, A., M. Ohtsuki, K. Polyak, J.M. Roberts, and J. Massagué. 1993. Negative regulation of Gl in mammalian cells: Inhibition of cyclin E-dependent kinase by TGF- $\beta$. Science 260: 536-539.

Laiho, M., J.A. DeCaprio, J.W. Ludlow, D.M. Livingston, and J. Massagué. 1990. Growth inhibition by TGF- $\beta 1$ linked to suppression of retinoblastoma protein phosphorylation. Cell 62: 175-185. 
Lee, M.-H., I. Reynisdóttir, and J. Massagué. 1995. Cloning of p5 $7^{\text {Kip2 }}$, a cyclin-dependent kinase inhibitor with unique domain structure and tissue distribution. Genes \& Dev. 9: 639-649.

Lehman, T.A., R. Modali, P. Boukamp, J. Stanek, W.P. Bennet, J.A. Welsh, R.A. Metcalf, M.R. Stampfer, N. Fusenig, E.M. Rogan, and C.C. Harris. 1993. p53 Mutations in human immortalized epithelial cell lines. Carcinogenesis 14: 833-839.

Luo, Y., J. Hurwitz, and J. Massagué. 1995. Cell cycle inhibition by independent CDK and PCNA binding domains in $\mathrm{p} 21^{\text {Cip1 }}$. Nature 375: 159-161.

Massagué, J. 1990. The transforming growth factor- $\beta 1$ family. Annu. Rev. Cell Biol. 6: 597-641.

Matsuoka, S., M. Edwards, C. Bai, S. Parker, P. Zhang, A. Baldini, J.W. Harper, and S.J. Elledge. 1995. p5 $7^{\text {Kip2 }}$, a structurally distinct member of the Cipl cdk inhibitor family, is a candidate tumor suppressor gene. Genes \& Dev. 9: 650-662.

Matsushime, H., M.E. Ewen, D.K. Strom, J.-Y. Kato, S.K. Hanks, M.F. Roussel, and C.J. Sherr. 1992. Identification and properties of an atypical catalytic subunit (p34PSK-J3/cdk4) for mammalian D type G1 cyclins. Cell 71: 323-334.

Matsushime, H., D.E. Quelle, S.A. Shurtleff, M. Shibuya, C.J. Sherr, and J.-Y. Kato. 1994. D-type cyclin-dependent kinase activity in mammalian cells. Mol. Cell Biol. 14: 2066-2076.

Meyerson, M. and Harlow, E. 1994. Identification of G1 kinase activity for cdk6, a novel cyclin D partner. Mol. Cell. Biol. 14: 2077-2086.

Mori, T., K. Miura, T. Aoki, T. Nishihara, S. Mori, and M. Nakamura. 1994. Frequent somatic mutation of MTS1/CDK4I gene in esophageal squamous cell carcinoma. Cancer Res. 54: 3396-3397.

Moses, H.L., E.Y. Yang, and J. Pietenpol. 1990. TGF- $\beta$ stimulation and inhibition of cell proliferation: New mechanistic insights. Cell 63: 245-247.

Nakanishi, M., R.S. Rovetorye, G.R. Adamai, O.M. PereiraSmith, and J.R. Smith. 1995. Identification of the active region of the DNA synthesis ihibitory gene $\mathrm{p} 21^{\text {Sdil/CIP1/WAFl }}$. EMBO J. 14: 555-563.

Nobori, T., K. Miura, D.J. Wu, A. Lois, K. Takabayashi, and D.A. Carson. 1994. Deletions of the cyclin-dependent kinase-4 inhibitor gene in multiple human cancers. Nature 368: 753756.

Noda, A., Y. Ning, S.F. Venable, O.M. Pereira-Smith, and J.R. Smith. 1994. Cloning of senescent cell-derived inhibitors of DNA synthesis using an expression screen. Exp. Cell Res. 211: 90-98.

Nourse, J., E. Firpo, M.W. Flanagan, S. Coats, K. Polyak, M.-H. Lee, J. Massagué, G.R. Crabtree, and J.M. Roberts. 1994. Interleukin-2-mediated elimination of the $\mathrm{p} 27^{\mathrm{Kip} 1}$ cyclin-dependent kinase inhibitor prevented by rapamycin. Nature 372: $570-573$.

Ohtsubo, M. and J.M. Roberts. 1993. Cyclin dependent regulation of Gl in mammalian fibroblasts. Science 259: 19081912.

Parker, S.B., G. Eichele, P. Zhang, A Rawls, A.T. Sands, A. Bradley, E.N. Olson, Harper, J.W., and S.J. Elledge. 1995. p53independent expression of $\mathrm{p} 21^{\mathrm{Cip} 1}$ in muscle and other terminally differentiating cells. Science 267: 1024-1027.

Peter, M. and I. Herskowitz. 1994a. Direct inhibition of the yeast cyclin-dependent kinase Cdc28-Cln by Farl. Science 265: 1228-1231.

- 1994b. Joining the complex: Cyclin-dependent kinase inhibitory proteins and the cell cycle. Cell 79: 181-184.

Peters, G. 1994. Stifled by inhibitions. Nature 371: 204-205.

Pietenpol, I.A., R.W. Stein, E. Moran, P. Yacuik, R. Schlegel, R.M. Lyons, R.M. Pittelkow, K. Múnger, P.M. Howley, and
H.L. Moses. 1990. TGF- $\beta 1$ inhibition of c-myc transcription and growth in keratinocytes is abrogated by viral transforming protein with pRB binding domains. Cell 61: 777-785.

Polyak, K., J. -Y. Kato, M.J. Solomon, C.J. Sherr, J. Massagué, J.M. Roberts, and A. Koff. 1994a. p2 ${ }^{\text {Kip1 }}$, a cyclin-Cdk inhibitor, links transforming growth factor- $\beta$ and contact inhibition to cell cycle arrest. Genes \& Dev. 8: 9-22.

Polyak, K., M.-H. Lee, H. Erdjument-Bromage, A. Koff, P. Tempst, J.M. Roberts, and J. Massagué. 1994b. Cloning of $\mathrm{p} 27^{\mathrm{Kipl}}$ a cyclin-cdk inhibitor and a potential mediator of extracellular antimitogenic signals. Cell 78: 59-66.

Quelle, D.E., R.A. Ashmun, S.A. Shurtleff, J.-Y. Kato, D. BarSagi, M.F. Roussel, and C.J. Sherr. 1993. Overexpression of mouse $D$-type cyclins accelerates $G_{1}$ phase in rodent fibroblasts. Genes \& Dev. 7: 1559-157.

Satterwhite, D.J., M.E. Aakre, A.E. Gorska, and H.L. Moses. 1994. Inhibition of cell growth by TGF $\beta$ is associated with inhibition of B-myb and cyclin A in both BALB/MK and MvlLu cells. Cell Growth Differ. 5: 789-799.

Serrano, M., G.J. Hannon, and D. Beach. 1993. A new regulatory motif in cell cycle control causing specific inhibition of cyclin D/CDK4. Nature 366: 704-707.

Sherr, C.J. 1993. Mammalian G1 cyclins. Cell 73: 1059-1065. . 1994. Gl phase progression: Cycling on cue. Cell 79: $551-555$.

Sherr, C.J. and J.M. Roberts. 1995. Inhibitors of mammalian $\mathrm{G}_{1}$ cyclin-dependent kinases. Genes \& Dev. 9: 1149-1163.

Slingerland, J.M., L. Hengst, C. Pan, D. Alexander, M. Stampfer, and S.I. Reed. 1994. A novel inhibitor of cyclin-cdk activity detected in transforming growth factor $\beta$-arrested epithelial cells. Mol. Cell. Biol. 14: 3683-3694.

Toyoshima, H. and T. Hunter. 1994. p27, a novel inhibitor of G1 cyclin-Cdk protein kinase activity, is related to p21. Cell 78: 67-74.

Waga, S., G.J. Hannon, D. Beach, and B. Stillman. 1994. The p21 inhibitor of cyclin-dependent kinases controls DNA replication by interaction with PCNA. Nature 369: 574-578.

Warbrick, E., D.P. Lane, D.M. Glover, and L.S. Cox. 1995. A small peptide inhibitor of DNA replication defines the site of interaction between the cyclin-dependent kinase inhibitor p21WAFl and proliferating cell nuclear antigen. Curr. Biol. 5: 275-282.

Xiong, Y., G.J. Hannon, H. Zhang, D. Casso, R. Kobayashi, and D. Beach. 1993. p21 is a universal inhibitor of cyclin kinases. Nature 366: 701-704.

Zentella, A., F.M.B. Weis, D.A. Ralph, M. Laiho, and J. Massagué. 1991. Early gene responses to transforming growth factor- $\beta$ in cells lacking growth suppressive RB function. Mol. Cell. Biol. 11: 4952-4958. 